SR/OOG/94-03

Distribution Category UC-950

\title{
The Energy Information Administration's
} Assessment of Reformulated Gasoline: An Update

\author{
December 1994 \\ Energy Information Administration \\ Office of Oil and Gas \\ U.S. Department of Energy \\ Washington, DC 20585
}

Service reports are prepared by EIA upon special request and may be based on assumptions specified by the requestor. Information regarding the request for this report is included in the Preface. 


\section{Contacts}

The report, The Energy Information Administration's Assessment of Reformulated Gasoline: An Update, was prepared by the Office of Oil and Gas. General information concerning this report may be obtained from Diane Lique (202-586-6401), Director of the Office of Oil and Gas.

Questions concerning the contents of the report may be referred to John Cook (202-586-5214), Director of the Petroleum Marketing Division, or to Aileen Bohn (202-586-4255), of the Petroleum Supply Division, who coordinated the development of the report. The following authors contributed to the preparation of the report.
Aileen Bohn
Michael Burdette*
Michael Conner
Charles Dale
William Farrell*
John Hackworth*

\author{
Diana House \\ Paul Kasulis* \\ Tancred Lidderdale \\ Joanne Shore* \\ James Tsikerdanos* \\ John Zyren
}

- The author is employed as a contractor to the Energy Information Administration. 


\section{DISCLAIMER}

This report was prepared as an account of work sponsored by an agency of the United States Government. Neither the United States Government nor any agency thereof, nor any of their employees, make any warranty, express or implied, or assumes any legal liability or responsibility for the accuracy, completeness, or usefulness of any information, apparatus, product, or process disclosed, or represents that its use would not infringe privately owned rights. Reference herein to any specific commercial product, process, or service by trade name, trademark, manufacturer, or otherwise does not necessarily constitute or imply its endorsement, recommendation, or favoring by the United States Government or any agency thereof. The views and opinions of authors expressed herein do not necessarily state or reflect those of the United States Government or any agency thereof. 


\section{DISCLAIMER}

Portions of this document may be illegible in electronic image products. Images are produced from the best available original document. 


\section{Preface}

On June 28, 1994, a hearing was held by the U.S. House of Representatives, Committee on Energy and Commerce, Subcommittee on Oversight and Investigations relating to the implementation of the 1990 amendments to the Clean Air Act. As a result of the hearing, the Subcommittee Chairman, Congressman John D. Dingell, sent a letter, dated June 28, 1994, to Ms. Susan Tierney, Assistant Secretary for Policy, Planning and Program Evaluation, of the U.S. Department of Energy. He wrote:

"I request that the Energy Information Administration (EIA) conduct an analysis by October 1994 which examines the final RFG rule, the many guidances, interpretations, etc., the pending rules (if adopted), the ability of the distribution system to handle these matters, including identifying any pipeline and tankage problems, the extent to which smaller refiners will not produce RFG and potentially create supply problems, and all other relevant factors affecting gasoline supplies nationwide, regionally, and by State. The analysis should include expected RFG supply sources beginning December 1, 1994, for each Sub-PADD in PADD I from local refineries, pipelines, barges, and imports...."

This report concludes a two-part study; Part I was published as The Energy Information Administration's Assessment of Reformulated Gasoline, Volumes 1 and 2. The data contained herein updates EIA's previous findings and analyses on reformulated gasoline as it affects the petroleum industry. These data should assist members of the Congress, Federal, State and local governments, analysts, researchers, the media, and academia in understanding the reformulated gasoline program and the current status of implementation. 


\section{Contents}

Page

1. Introduction $\ldots \ldots \ldots \ldots \ldots \ldots \ldots \ldots \ldots \ldots \ldots \ldots \ldots \ldots \ldots \ldots \ldots \ldots \ldots$

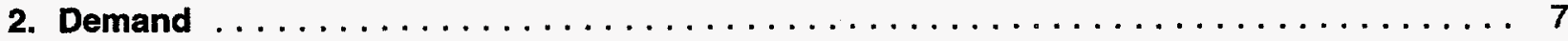

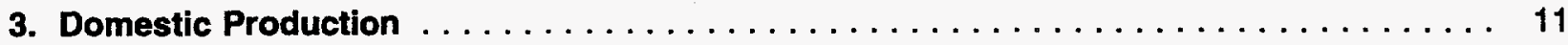

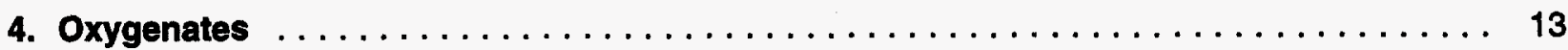

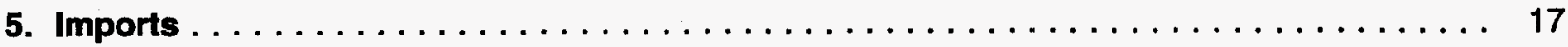

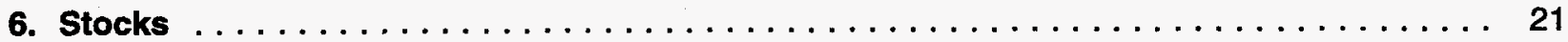

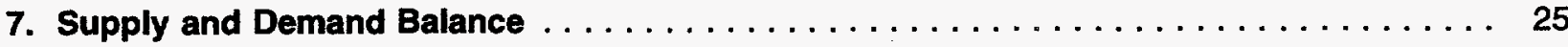

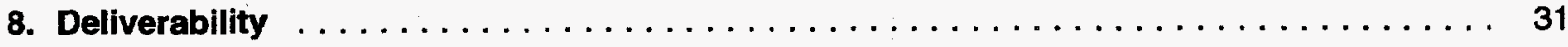

9. Prices $\ldots \ldots \ldots \ldots \ldots \ldots \ldots \ldots \ldots \ldots \ldots \ldots \ldots \ldots \ldots \ldots \ldots \ldots \ldots \ldots \ldots \ldots$

10. Recent Government Activity $\ldots \ldots \ldots \ldots \ldots \ldots \ldots \ldots \ldots \ldots \ldots \ldots \ldots \ldots \ldots$ 


\section{Tables}

1. Estimated Motor Gasoline Demand by Type and Region for December 1994 . . . . . . . . . . 9

2. EIA Market Clearing Estimates of Motor Gasoline Production by PADD, December $1994 \ldots \ldots 12$

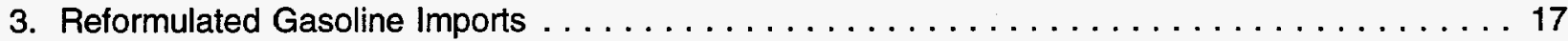

4. Weekly RFG Stocks (November 25, 1994 and December 2, 1994) and Forecast . . . . . . . 21

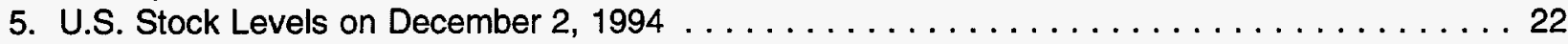

6. Market Clearing Estimates by Type of Gasoline, December $1994 \ldots \ldots \ldots \ldots \ldots \ldots \ldots \ldots$

7. RFG Market Clearing Estimates (Including OPRG), December $1994 \ldots \ldots \ldots \ldots \ldots \ldots . .27$

8. January U.S. Total RFG Supply and Demand Balance Update . . . . . . . . . . . . . 29

\section{Figures}

1. Regional Reformulated Gasoline Production and Demand Areas as of January 1, $1995 \ldots \ldots$. . . vi

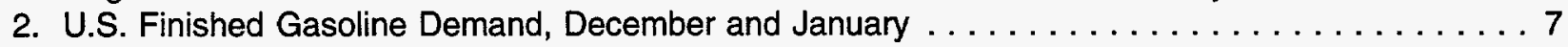

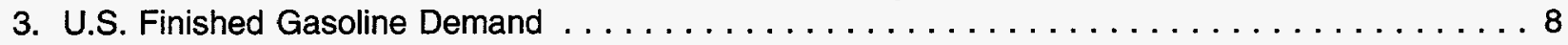

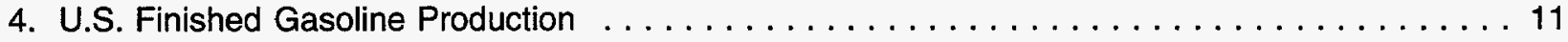

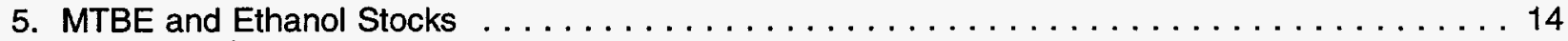

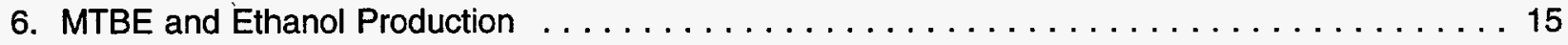

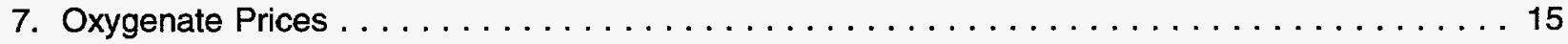

8. Potential RFG Supplies Available to the United States $\ldots \ldots \ldots \ldots \ldots \ldots \ldots \ldots \ldots \ldots \ldots 18$

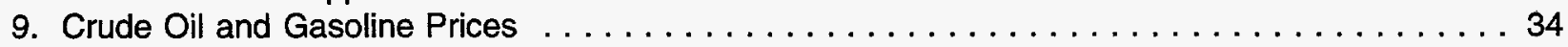

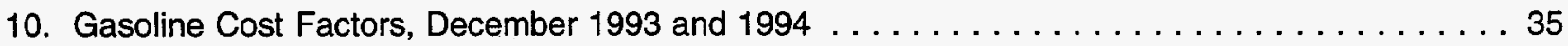


Figure 1. Reformulated Gasoline Production and Demand Areas as of January 1, 1995

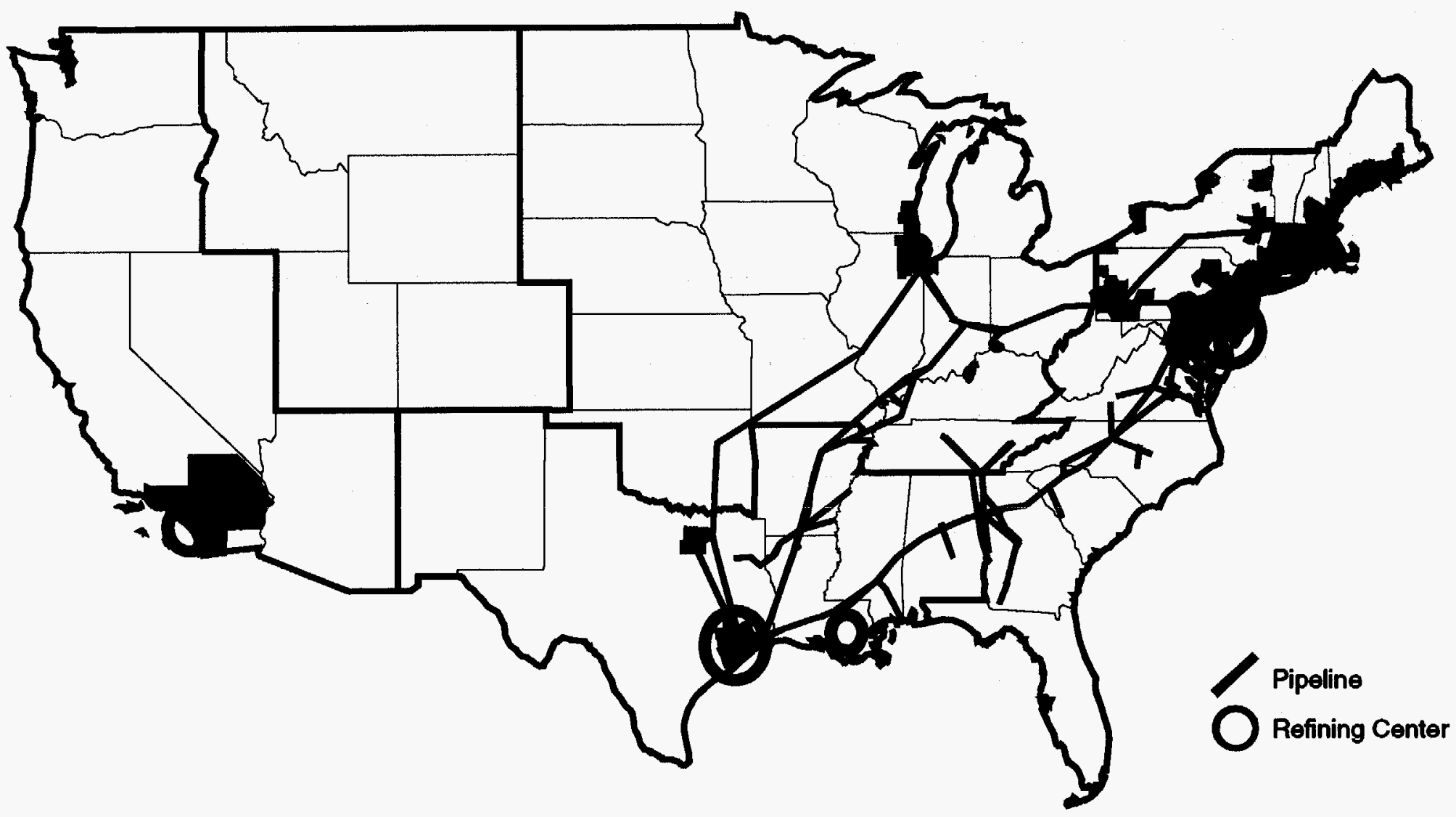

Sources: Demand areas derived from: "Regulation of Fuels and Fuel Additives; Standards for Reformulated and Conventional Gasoline; Final Rule," Environmental Protection Agency (EPA), December 15, 1993. "Regulation of Fuels and Fuel Additives: Standards for Reformulated and Conventional Gasoline," EPA, June 30, 1994. "Reformulated Gasoline and Anti-Dumping Questions and Answers," EPA July 1,1994. Pipelines from Petroleum Storage \& Transportation, vol. 2, the National Petroleum Council, 1989. 


\section{Introduction}

\section{Background}

On January 1,1995 , motorists in designated areas throughout the country will begin using reformulated gasoline (RFG), a cleaner motor gasoline designed to significantly reduce the pollutants emitted by motor vehicles. The Clean Air Act Amendments of 1990 require RFG to be the only gasoline sold in the nine most severe ozone nonattainment metropolitan areas. ${ }^{1}$ In addition, 14 States and the District of Columbia decided voluntarily to place additional serious or moderate nonattainment areas into the program. These "opt-in" areas include a population of nearly 30 million, in addition to the 60 million people in the mandatory RFG areas. The RFG program will be implemented through regulations promulgated by the Environmental Protection Agency (EPA). Once the program is fully realized, RFG is expected to represent about a third of the U.S. gasoline market.

At the request of Congressman John Dingell, Chairman of the Subcommittee on Oversight and Investigations of the Energy and Commerce Committee, the Energy Information Administration (EIA) initiated a study to assess the implementation of the RFG program. EIA was asked to identify any problems that might be expected to occur during the start-up of the RFG program in early 1995 , and to describe those events that could potentially cause significant disruptions to the program over the longer term. Part I of the study was delivered to Congress October 3, 1994, and this report comprises Part II, which is an update of Part I.

The RFG program contains one of the most complex sets of product specifications ever met by the refining industry. To meet RFG product quality standards, refiners added processing steps and blending components. The fundamental differences between RFG and conventional gasoline are the reduction of aromatics (particularly benzene) and inclusion of oxygenates to enhance combustion and reduce evaporative emissions. ${ }^{2}$

In addition to refinery changes, the product delivery system is faced with reduced flexibility due to an increased number of gasoline products that must be kept segregated. Some product terminals are storing fewer products due to limited tankage; product exchange flexibility is diminished; and some pipelines may experience throughput slowdowns.

Part I of the RFG assessment focused on the gasoline supply and demand status in January, when the RFG program will commence at the retail level. Analysis used in Part I was performed prior

\footnotetext{
${ }^{1}$ These ozone nonattainment areas are Baltimore, Chicago, Hartford, Houston, Los Angeles, Milwaukee, New York City, Philadelphia, and San Diego.

${ }^{2} \mathrm{~A}$ complete description of the RFG program is provided in The Energy Information Administration's Assessment of Reformulated Gasoline, Volumes 1 and 2, SR/OOG/94-02/1 and 2 (Washington, DC, October 1994).
} 
to any significant RFG production. For Part II, actual data through November allowed EIA to improve its estimates for January, and recent events such as the Colonial Pipeline disruption required analyzing the potential December supply and demand balance in some detail to ensure that the program was still on track. As of December 1, terminals can only supply certified RFG to retail stations in RFG areas. Thus, the RFG program was fully implemented through the wholesale level by December 1. In Part II, the December transition to January is described, and the January projection is updated.

\section{Review of Major Findings from Part II}

The fundamental finding of Part II of the RFG assessment is that the conclusion from Part I has not changed: Supplies are adequate to meet demand, but we face a tight supply-demand balance, typical of new product transitions, which leaves the system with relatively little ability to absorb an unexpected supply or delivery system disruption. A refinery outage in the Northeast or in Southern California, for example, could lead to shortages in those regions. In addition, the likelihood of local shortages (for example, a single county) are possible due to diminished system flexibility and the fact that in complex circumstances, everything may not work right the first time.

- Nationally, during December 1994, RFG supplies are expected to be sufficient to meet the estimated demand level of 2,608 thousand barrels per day (MBD); but the balance is tight, typical of new product transitions.

- RFG stocks entering December are low, but near the estimated levels reported in Part I of the study. Data reported to EIA show stocks on December 2 to be 38.9 million barrels (MMB), which is about 15 days of supply. Due to various uncertainties discussed below, actual stocks are estimated to range from 17 to 19 days of supply, which is still relatively low. Historically, finished motor gasoline stocks average 24 days of supply at the end of November. EIA's supply-demand balance estimates suggest only a small stock increase during the month, which is typical of conventional gasoline in December.

- Updated information for January helps to ease the tight balance, but does not provide enough stock build to lessen significantly the potential of shortages arising should an unexpected supply disruption occur. The updates for January include:

- Plans for increases in RFG production of about $100 \mathrm{MBD}$;

- Lower total gasoline demand estimates than shown in Part I of the study, resulting in lower demand for RFG of about $66 \mathrm{MBD}$;

- Import levels at least as high as those shown in Part I; and

- Production potential to add another 5 MMB in stocks due to the demand and productionplan changes. 
- Current prices for RFG are consistent with the costs underlying the product, and the difference between RFG and conventional gasoline prices indicates confidence in supply.

- Conventional gasoline prices are higher than last year by about 6 cents per gallon, due mainly to increases in the cost of crude oil needed to make the product.

- The 4 to 6 cent-per-gallon wholesale price difference between RFG and conventional gasoline can be explained mainly by the cost of the oxygenates that displace some of the lower cost gasoline.

- On a cost basis alone, consumers can expect to pay as much as 15 cents per gallon more for RFG (not oxygenated program reformulated gasoline) this winter than they paid last winter for conventional, due mainly to cost increases in crude oil and to the cost of the oxygenates added to RFG.

- Consumers of oxygenated program reformulated gasoline (OPRG) and oxygenated gasoline can expect to pay 10 to 12 cents per gallon more than they paid for oxygenated gasoline last year, due mainly to increases in the cost of the oxygenate over last year and the higher cost of crude oil.

\section{Impacts of Recent Events}

Postponement of the Renewable Oxygenate Standard (ROS): The delay of ROS, the requirement that 30 percent of the oxygenates for RFG be derived from ethanol and other renewable sources, removes a large element of complexity from the already complex RFG program. As such, the delay is considered to increase the chances of a successful transition. The courts have called for hearings to be held in early 1995, prior to making a determination concerning ROS.

Decision to Require Importers to Use the U.S. Average Baseline: The potential for RFG imports may be reduced if foreign refiners are required to use the U.S. baseline for limiting emissions. Venezuela claims production capacity of about $100 \mathrm{MBD}$ of RFG for export to the United States if allowed to use its own baseline, rather than being subject to the stricter requirements of the 1990 U.S. average baseline. Given the tighter U.S. baseline requirements, some industry analysts have estimated likely exports to the United States at 32 to 82 MBD of RFG, depending on prevailing economics. ${ }^{3}$ Venezuela has asserted that by not according it equal treatment with U.S. refiners, the United States violated the General Agreement on Tariffs and Trade (GATT). A GATT panel has been formed to review this decision; however, as of December 7, 1994, a meeting date had not been established.

Colonial Pipeline Disruption: On October 20, 1994, the Colonial Pipeline, which transports petroleum products from Gulf Coast refineries to the East Coast, ruptured under severe conditions

${ }^{3}$ Petroleum Intelligence Weekly, September 19, 1994. 
created by torrential rains and flooding in the Houston, Texas area. By November 2, 1994, Colonial had reestablished pipeline movements of petroleum products from the Houston area by making temporary repairs to its No. 2 line across the river. Fortunately, this mishap, which potentially could have been disastrous for the RFG program, happened in the initial stage as the first RFG shipments were beginning to move to the Northeast. Quick response to the emergency minimized the impact.

Pennsylvania's Request to Opt-Out of the RFG Program: At the beginning of December, Pennsylvania petitioned EPA to remove 28 counties, representing about $170 \mathrm{MBD}$, or 7 percent of U.S. RFG demand, from the program. If the petition were approved immediately, the reduction in RFG demand in December would imply that production capacity is available to build another $5 \mathrm{MMB}$ of RFG stocks during the month. (This would only happen if price incentives were adequate to encourage the extra production.) Although the production may not materialize, knowing that it is available caused gasoline markets to soften. Spot prices fell 4 cents per gallon on December 2, 1994, after the Governor of Pennsylvania signed the legislation to withdraw. The immediate price response is further evidence of the apparent tight supply-demand balance. Pennsylvania's withdrawal, if approved, would ease that tightness to some extent, thereby improving the likelihood of a smooth transition.

\section{Data Uncertainties}

When new programs are introduced, it is not uncommon for companies: to experience problems understanding all aspects of the new program; to encounter difficulties in setting up internal company mechanisms to track information related to the program; and, to have difficulties in submitting reports that reflect how the program is being implemented. EIA has been concerned about the implementation of the RFG program, given its complexity with respect to both the fuel specifications and the regulations prescribing how the program will be implemented.

EIA has maintained a continuous dialogue with the companies that are reporting the RFG data in order to understand reporting problems as they arose and to assess their impact on RFG supplies. The following is a summary of the problems encountered or situations that exist. All of these points imply that the reported data may understate actual RFG supply levels.

- When RFG was first produced, it was reported by some companies as oxygenated or conventional gasoline since it was to be used to "flush" the system in preparation for the implementation of the program at the wholesale level on December 1, 1994. Once the system was "flushed," and the gasoline could meet the test specifications for RFG, terminal operators (or others) could then create the transfer documentation necessary to move the product to retail outlets as RFG. As this was done, terminal operators should have reclassified the gasoline as RFG and submitted this information to EIA.

- With the transition to RFG, some companies have encountered difficulty in capturing all volumes of RFG in their systems for reporting purposes, particularly those volumes moving by water. 
- Although EIA worked closely with industry in designing the data collection forms, no one recognized the need to break out reformulated blendstocks for oxygenate blending (RBOB) as a separate component of "blending components." . As a result, total RFG/RBOB production and inventories are understated by an estimated $82 \mathrm{MBD}$ and $2.5 \mathrm{MMB}$, respectively, as of December 2, 1994.

- With no historical reporting record for RFG volumes, EIA is not currently able to impute for non-response or to adjust estimates for non-sampled producers and stockholders that may have small volumes of RFG.

EIA will continue to work closely with industry to resolve reporting difficulties as they arise.

\section{Study Approach}

Part I of the study, delivered to Congress October 3,1994, was published in two volumes entitled The Energy Information Administration's Assessment of Reformulated Gasoline. Part I of the study was largely based on planning estimates and forecasts developed in advance of the actual production, importation, and stocking of RFG. Part II, an update to Part I, is based on: supply data from ongoing EIA surveys; the results of a special voluntary survey performed in August 1994 for Part I of the study, which collected information on company plans pertaining to RFG; voluntary updated information to the special survey; and prices and other publicly available information. Like the earlier version, Part II involves interaction among departments within the U.S. Department of Energy, EPA and industry personnel involved in the supply and distribution of RFG. 



\section{Demand}

The fundamental question explored in this report is the ability of RFG production and imports to both build adequate stocks and meet demand. ${ }^{4}$ In this section, EIA describes its update to the demand target against which supply adequacy can be measured.

Part I of the RFG assessment was finished in October and focused on gasoline supply and demand in January, when the RFG program will commence at the retail level. Actual data through November now allow us to improve our estimates for December and January. As of December 1 , terminals can supply only certified RFG to retail stations in RFG areas. Thus, the RFG program was fully implemented through the wholesale level by December 1. As a result, RFG production and imports during December must satisfy December demand and primary stocklevel changes, although retail stations are not required to sell certified RFG until January 1.

Figure 2. U.S. Finished Gasoline Demand, December and January

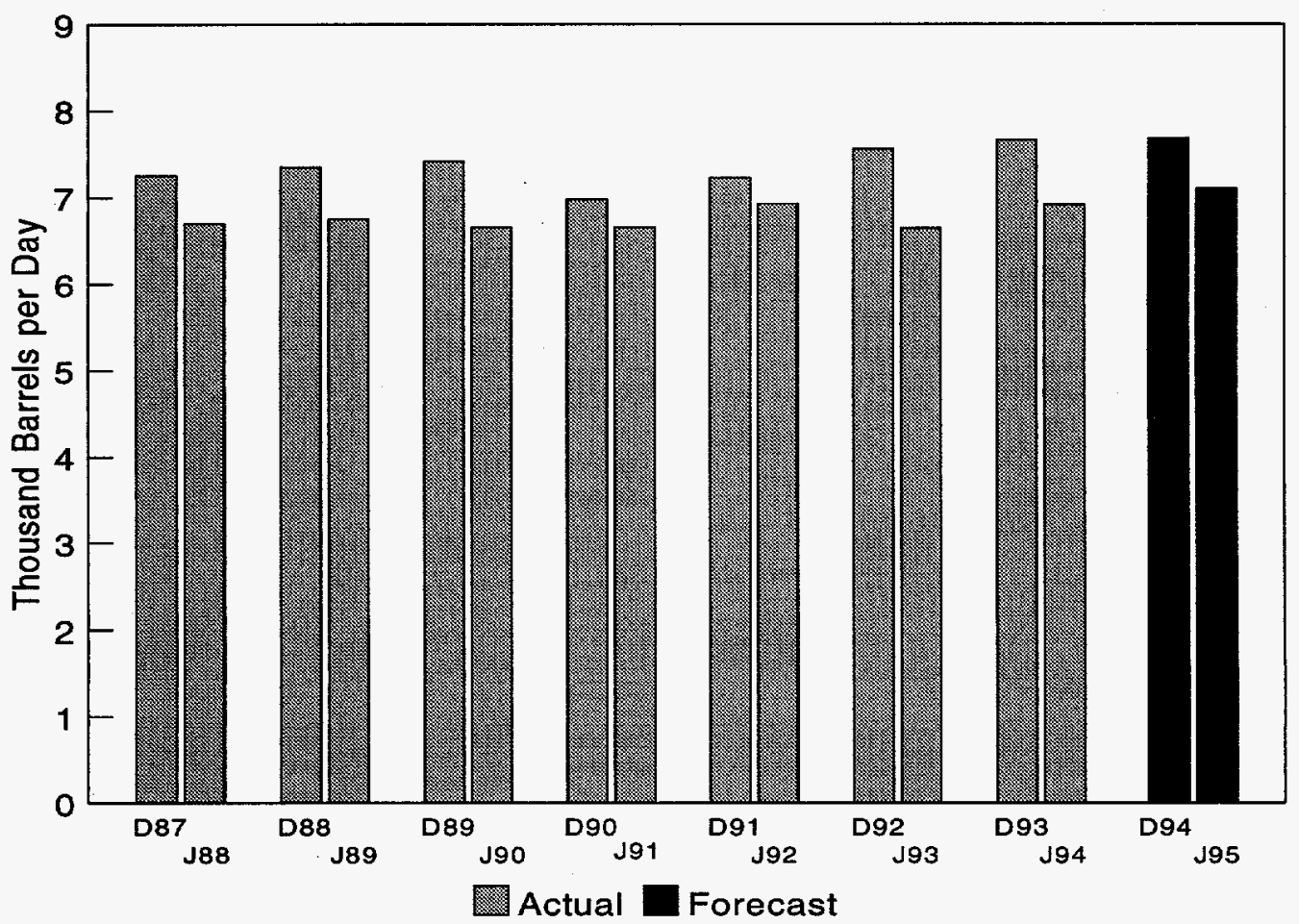

Sources: EIA Petroleum Supply Annual 1993 and prior issues, Petroleum Supply Monthly (March 1994), and EIA forecasts.

${ }^{4}$ Demand historically is estimated from petroleum supply data as: Production + Net Imports + Stock Draws - Stock Builds. 
December total motor gasoline demand is estimated to be $7,683 \mathrm{MBD}$, which is slightly higher than that in December 1993 (which was at a record level of 7,661 MBD) and over 8 percent higher than the latest EIA estimates for January 1995 demand (Figure 2). Record December 1993 gasoline demand was primarily the result of exceptionally strong economic growth during the fourth quarter last year. Although the economy is not expected to be quite as strong this December as last, many recent economic indicators suggest similar high levels of gasoline demand. The December 1994 demand estimate also is consistent with an upward trend in gasoline demand over the past few years.

For the first nine months of 1994, gasoline demand averaged 1.4 percent higher than in 1993. Historically, demand has been higher in December than in January (Figure 2). In December, holiday travel is high, and the weather generally is not as bad for travel as in January. Figure 3 shows historical finished gasoline demand, along with EIA's latest estimate for December 1994.

The breakdown of estimated December gasoline demand into RFG, OPRG, oxygenated gasoline and conventional gasoline is shown in Table 1.

Figure 3. U.S. Finished Gasoline Demand

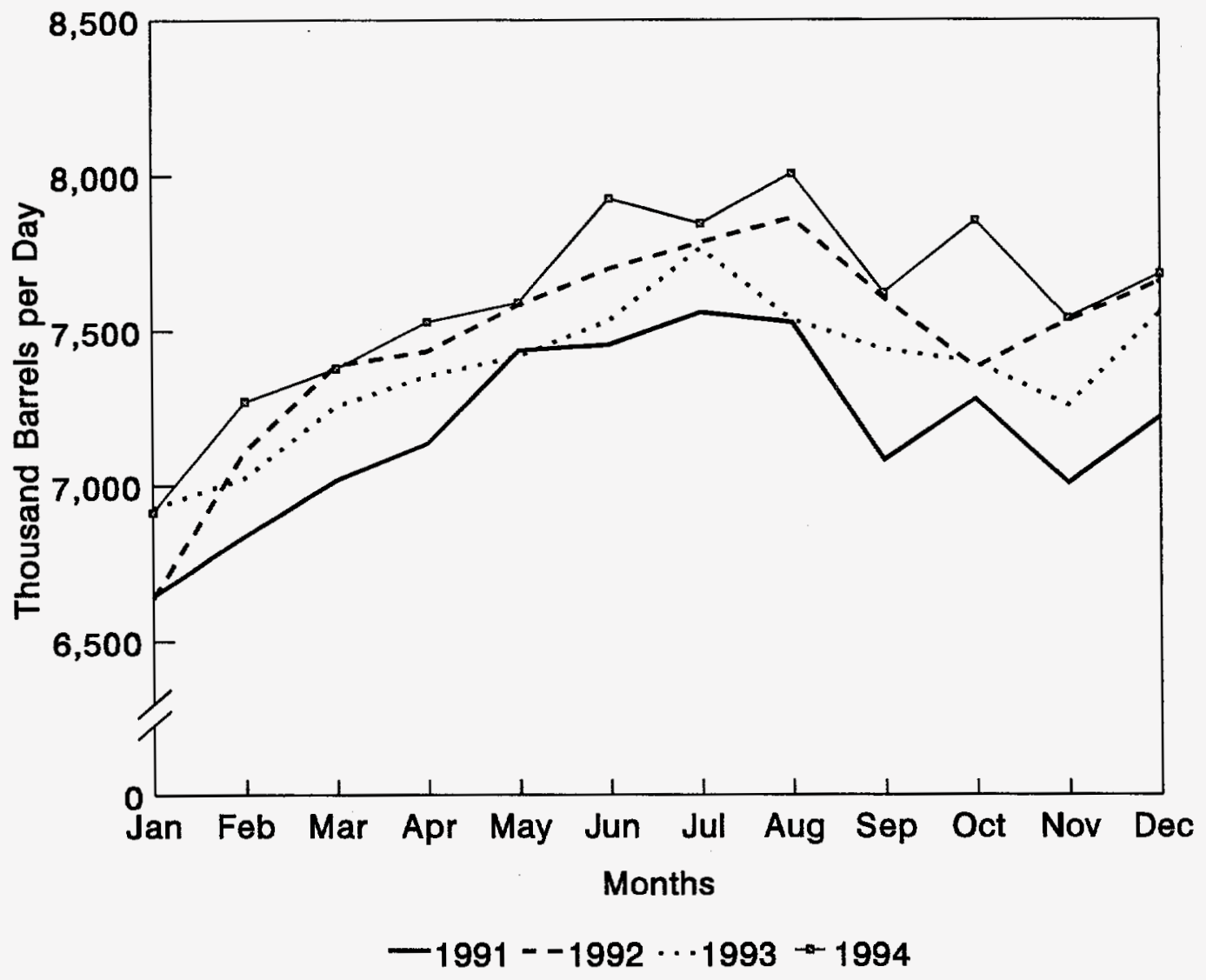

Source: EIA Petroleum Supply Annual 1993 and prior issues, Petroleum Supply Monthly (November 1994 and prior issues), and EIA estimates. 
Table 1. Estimated Motor Gasoline Demand by Type and Region for December 1994 (Thousand Barrels per Day)

\begin{tabular}{|c|c|c|c|c|c|c|}
\hline PADD & RFG & OPRG & $\begin{array}{c}\text { Total } \\
\text { RFG }\end{array}$ & Oxygenated & Conventional & Total \\
\hline IA & 306 & 27 & 333 & 0 & 18 & 351 \\
\hline IB & 241 & 706 & 947 & 0 & 99 & 1,046 \\
\hline IC & 71 & 51 & 122 & 56 & 999 & 1,177 \\
\hline I Total & 618 & 784 & 1,402 & 56 & 1,116 & 2,574 \\
\hline II Total & 374 & 0 & 374 & 84 & 1,893 & 2,351 \\
\hline III Total & 287 & 0 & 287 & 42 & 846 & 1,175 \\
\hline IV Total & 0 & 0 & 0 & 96 & 142 & 238 \\
\hline $\begin{array}{l}V \\
\text { excl } \\
C A\end{array}$ & 0 & 0 & 0 & 272 & 175 & 447 \\
\hline $\mathrm{CA}$ & 545 & 0 & 545 & 353 & 0 & 898 \\
\hline V Total & 545 & 0 & 545 & 625 & 175 & 1,345 \\
\hline Total & 1,824 & 784 & 2,608 & 903 & 4,172 & 7,683 \\
\hline
\end{tabular}

Note: Totals may not equal the sum of components due to rounding. California RFG is shown as RFG rather than OPRG; although 2 weight percent oxygen content of the RFG also meets California's OPRG requirements.

Source: EIA estimates.

These estimates of gasoline demand include the same assumptions for spillover ${ }^{5}$ of RFG into attainment areas, fuel efficiency, ${ }^{6}$ and price elasticity ${ }^{7}$ as were described for the estimates of January demand in Part I of this report. The total projected gasoline demand of 7,683 MBD in

\footnotetext{
${ }^{5}$ Spillover was estimated at 5 percent.

${ }^{6}$ Demand for RFG, OPRG, and oxygenated gasoline is increased by 1.7 to 2.0 percent to compensate for lower fuel efficiency.

${ }^{7}$ EIA assumes a decrease of about 16 thousand barrels per day in total U.S. RFG demand in response to an anticipated price increase at the pump.
} 
December 1994 is consistent with that published in EIA's Short-Term Energy Outlook. ${ }^{8}$ RFG and OPRG demand of 2,608 MBD (about 34 percent of total) is based on the proportion of the population residing in RFG areas, adjusted for spillover. In this forecast, spillover contributes about $124 \mathrm{MBD}$ to demand for RFG in December (or about $25 \mathrm{MBD}$ for each percentage point of spillover).

The demand estimates shown in Table 1 include the same nonattainment regions considered in Part I of the study. (Recall that areas participating in the RFG program consist of both mandatory participation areas and areas that opted in voluntarily.) Some States have been discussing opting out of participation in the RFG program. At the beginning of December, Pennsylvania petitioned EPA to remove 28 counties, representing about $170 \mathrm{MBD}$, or 7 percent, of U.S. RFG demand, from the program. (The Philadelphia area and four surrounding counties in Southeastern Pennsylvania are mandated to stay in the program.) As of December 7, 1994, EPA had not reached a decision on the Pennsylvania request.

The latest EIA data on finished gasoline product supplied suggest that January gasoline demand may be lower than the 7,290 MBD forecast in Part I of the study. EIA's latest estimates indicate demand may be only about 7,100 MBD. The reduction in total gasoline demand of $190 \mathrm{MBD}$ indicates a reduction in January RFG demand of about $66 \mathrm{MBD}$ from the 2,519 MBD published in October.

${ }^{8}$ Energy Information Administration, Short-Term Energy Outlook, Fourth Quarter, DOE/EIA-0202 (94/4Q) (Washington, DC, November 1994). 


\section{Domestic Production}

Domestic production of RFG was first reported during the week ending September 23, 1994. Then on October 20,1994, the Colonial Pipeline ruptured, and refiners struggled to maintain supplies of conventional and oxygenated gasoline. Refinery capacity utilization has recovered from a low of 86.8 percent of operable capacity reported for the week ending October 28, 1994 to 95.0 percent for the week ending December 2, 1994. Production of RFG has increased steadily during November 1994 and now appears on track to meet the projected December 1994 and January 1995 levels (Figure 4).

Figure 4. U.S. Finished Gasoline Production

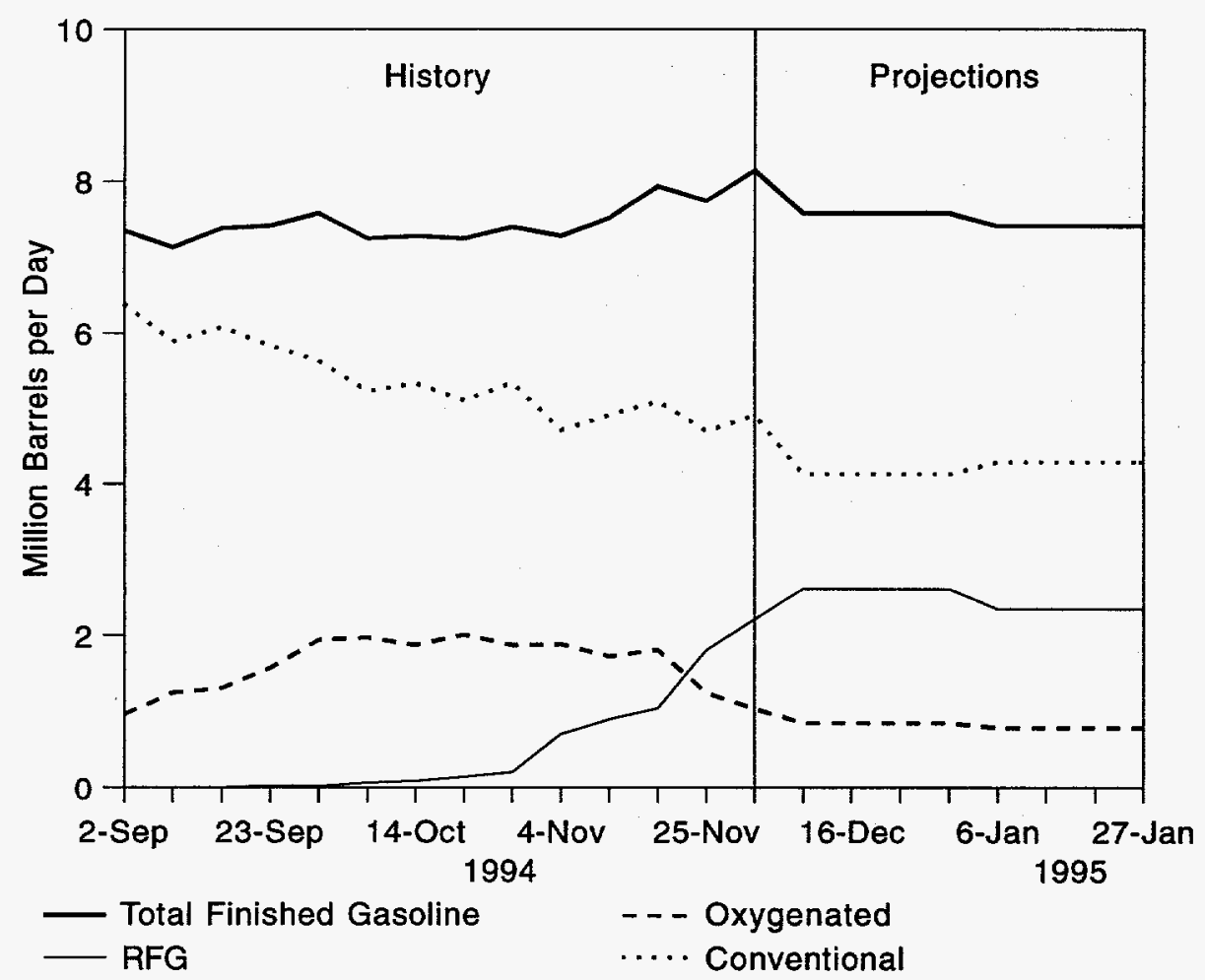

Source: EIA Weekly Petroleum Status Report, various issues and EIA estimates.

In Part I of the RFG assessment, the production plans of the petroleum industry to meet demand in January were summarized. These results were taken from a voluntary survey of U.S. refiners conducted in August 1994. For Part II of this study, the largest producers of RFG were recontacted by EIA during October and November 1994, to determine if their RFG production plans for December 1994 and January 1995 had changed since the original survey. The refiners that responded account for about 75 percent of projected domestic RFG production. The results of the resurvey indicate that production of RFG in January 1995 is now expected to be 
about 100 MBD higher than originally projected by EIA. The largest increases in planned production were reported for refineries in PADD I (46 MBD) and PADD III (57 MBD). Refineries in PADD V reported a planned increase in RFG production during January 1995 of $8 \mathrm{MBD}$, and PADD II refineries lowered their RFG production forecast by $8 \mathrm{MBD}$. These revised forecasts indicate that refiners may smooth their production response to the supply disruption caused by the October Colonial Pipeline rupture and the current low RFG inventory levels into the first quarter of 1995.

A December 1994 "EIA Market Clearing Estimate" of gasoline production was prepared using the EIA surveys of refiners and EIA's estimates of production from nonrespondents (Table 2). ${ }^{9}$

Table 2. EIA Market Clearing Estimate of Motor Gasoline Production by PADD, December 1994

(Thousand Barrels per Day)

\begin{tabular}{lrrrr}
\hline & \multicolumn{4}{c}{ Gasoline Type } \\
\cline { 2 - 5 } \multicolumn{1}{c}{ Production Area } & Conventional & Oxygenated & RFG & Total \\
\hline PADD I & 114 & 20 & 677 & 811 \\
PADD II & 1,452 & 136 & 292 & 1,880 \\
PADD III & 2,311 & 95 & 1,029 & 3,435 \\
PADD IV & 195 & 40 & 0 & 235 \\
PADD V & 212 & 580 & 528 & 1,320 \\
Total & 4,284 & 871 & 2,526 & 7,681 \\
\hline
\end{tabular}

Source: EIA estimates.

${ }^{9}$ For a review of the methodology used in developing this estimate refer to: Energy Information Administration, The Energy Information Administration's Assessment of Reformulated Gasoline, Volume 1, SR/OOG/94-02/1 (Washington, DC, October 1994), pp. 7-11. 


\section{Oxygenates}

There appear to be ample stocks and production capability of oxygenates to meet demand during the transition period to RFG in December and January. Oxygenates are a key blending component in the RFG program, and their prices are a large contributor to the cost differential between RFG and conventional gasoline. The two most important oxygenates are methyl tertiary butyl ether (MTBE) and ethanol. MTBE is produced by chemically combining methanol and isobutylene, so methanol price changes are quickly reflected in MTBE price changes. Ethanol is an alcohol derived mostly from corn production.

\section{Supply and Demand}

The demand for oxygenates has been steadily growing, and is expected to grow considerably in 1995 due to the RFG program. RFG requires about 11 volume percent of MTBE to meet its 2.0 weight percent oxygen requirement, whereas conventional gasoline being replaced by RFG contains essentially no oxygenates. The annual demand for MTBE-equivalent oxygenates was $320 \mathrm{MBD}$ in 1993, an estimated $360 \mathrm{MBD}$ in 1994, and will be an estimated $480 \mathrm{MBD}$ in 1995. Ethanol provided about half the MTBE-equivalent oxygenate volume consumed in 1993 and 1994, but that percentage will fall to about 40 percent in 1995 because of the difficulty of transporting ethanol to areas such as the Northeast where the demand for oxygenates is growing due to the use of RFG.

The demand for MTBE alone is projected to rise from an annual average of 182 MBD in 1994 to $284 \mathrm{MBD}$ in 1995, the difference being attributable to RFG demand. In the peak month of January 1995 (when oxygenated gasoline and OPRG are required in addition to RFG), MTBE demand is projected to be $311 \mathrm{MBD}$, a significantly higher demand level than the $223 \mathrm{MBD}$ value for December 1993 and 199 MBD value for January 1994.

At the end of October 1994, MTBE and ethanol stocks were 19.4 million barrels and 2.2 million barrels, respectively. ${ }^{10}$ Figure 5 shows that MTBE stocks are higher than the year-earlier level of 13.1 million barrels.

Increased production of MTBE is one of the reasons for the increase in stocks in spite of the higher demand. MTBE production was $157 \mathrm{MBD}$ at its peak before the 1993/94 oxygenated gasoline season, increased to $166 \mathrm{MBD}$ in August 1994, and is expected to increase further to 200-225 MBD by January 1995 (Figure 6). Imports, which were about $30 \mathrm{MBD}$ in the peak $1993 / 94$ oxygenated gasoline season, are expected to be $60-80$ MBD in January 1995. The

\footnotetext{
${ }^{10}$ Weekly Petroleum Status Report, December 2, 1994, p. 33.
} 
Figure 5. MTBE and Ethanol Stocks

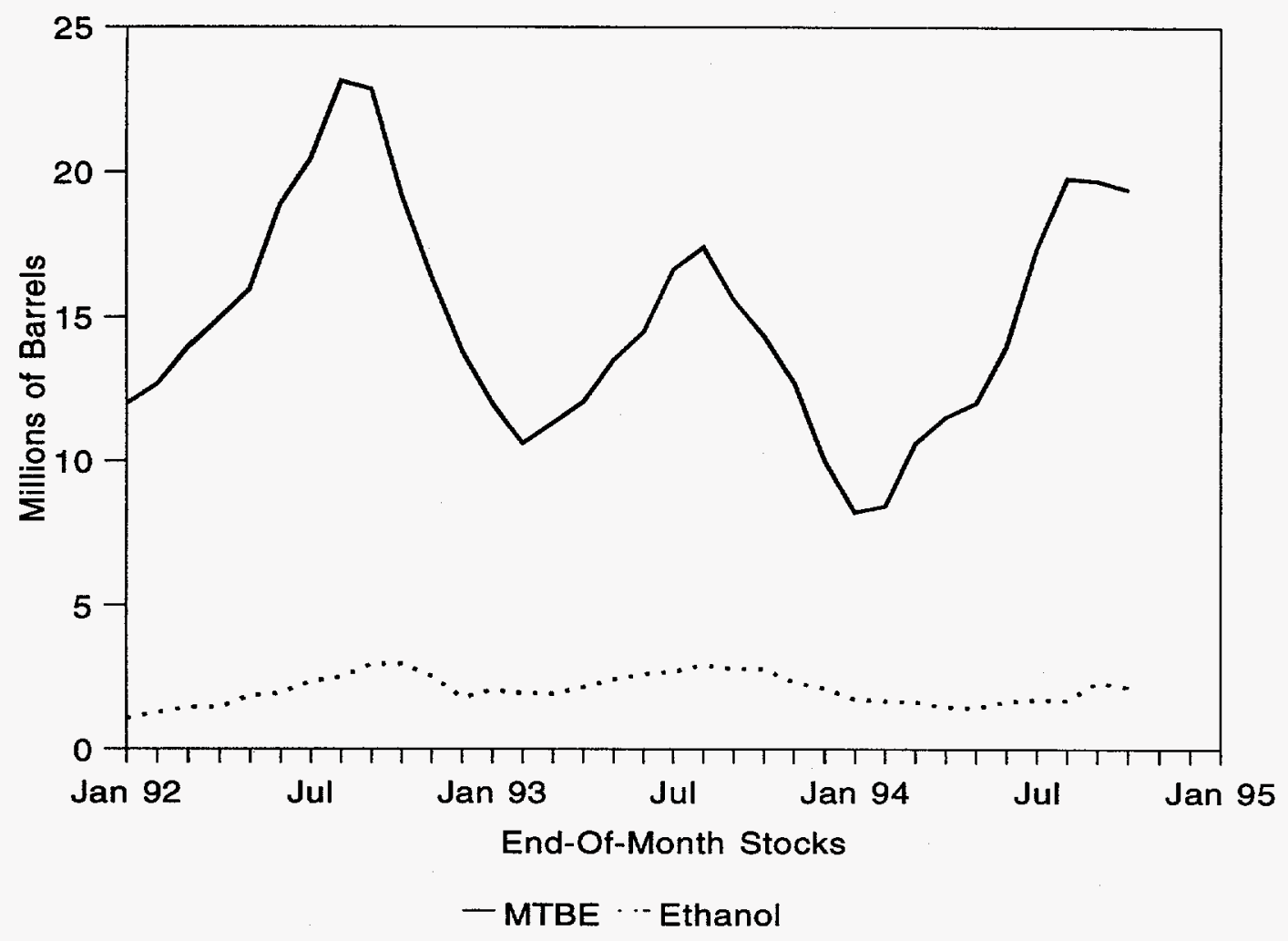

Source: Weekly Petroleum Status Report, November 25, 1994 and prior issues.

MTBE production capacity increases and anticipated import increases appear adequate to accommodate the MTBE demand increases arising from RFG.

Increases in demand and production of MTBE mean increased demand for methanol. Only 1 barrel of methanol is required for every 3-barrel increase in MTBE supplied, but methanol capacity increases have been fairly low. Thus, the methanol supply-demand balance has tightened more than that of MTBE. This was illustrated when some production problems over the summer resulted in dramatic price increases, which are discussed below.

Ethanol stocks in October 1994 were lower than the year-earlier level of 2.6 million barrels, but, as Figure 5 shows, production levels are higher for ethanol this year, reaching 2.8 million barrels in October compared to only 2.4 million barrels a year earlier. Additional production reduces the need for stocks when demand is relatively unchanged.

\section{Prices}

MTBE has shown significant price increases this past year, and underlying methanol price increases can explain most of the increase in MTBE prices (Figure 7). Methanol prices reached a new all-time high of $\$ 1.78$ per gallon in early October, after beginning 1994 at only 
Figure 6. MTBE and Ethanol Production

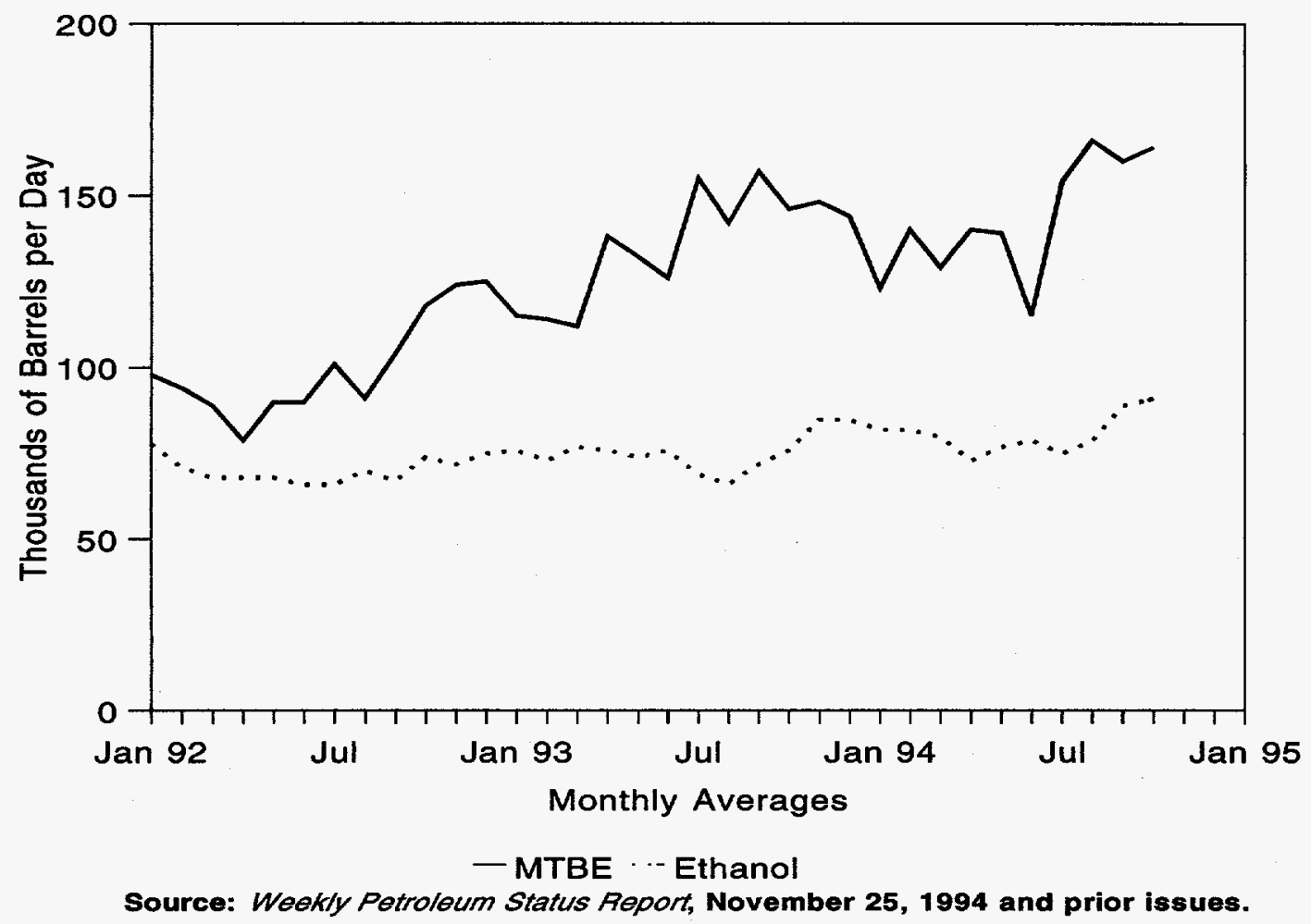

Figure 7. Oxygenate Prices

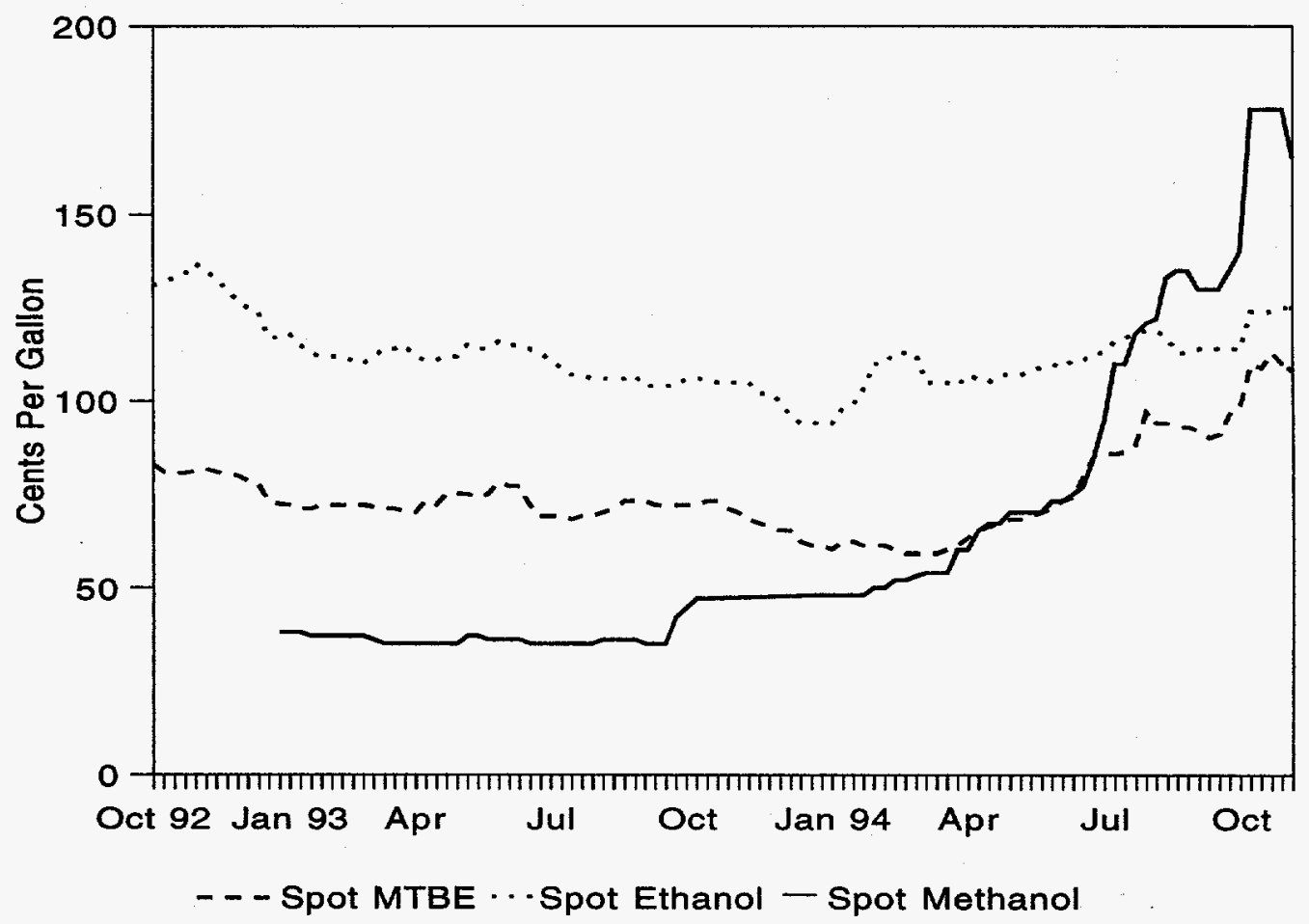

Source: Octane Week, various issues. 
48 cents per gallon. Methanol sold in the 32 to 45 cent-per-gallon range throughout 1992 and 1993 because of world-wide overcapacity. However, as discussed earlier, the increased demand for MTBE increased the demand for methanol and tightened the supply-demand balance. Total U.S. methanol production capacity is only $126 \mathrm{MBD}$, so when Lyondell closed its Channelview, Texas plant with a capacity of 15.2 MBD for maintenance in August, prices rose to $\$ 1.35$ per gallon. ${ }^{11}$ A fire at Enron's 10 MBD methanol plant in Pasadena, Texas, on October 12 pushed methanol prices to $\$ 1.78$ per gallon. ${ }^{12}$ About half of the plant's output was used by Enron to make MTBE, so when the plant returns to production in February 1995, it will help alleviate any potential tightness in MTBE supplies. Methanol prices appear to have peaked, and have since fallen back from their highs to $\$ 1.60$ per gallon at the end of November.

Spot prices of MTBE rose from 62 cents per gallon in January 1994 to $\$ 1.10$ per gallon in November. Methanol cost increases totaling $\$ 1.18$ per gallon add 40 cents per gallon to the cost of producing MTBE; therefore, most of the price increase observed in MTBE can be explained by the price increase in methanol. Ethanol prices have trended steadily upward in recent weeks, reaching $\$ 1.30$ per gallon at the end of November. The effects of these prices on reformulated gasoline prices are discussed later in this report.

${ }^{11}$ Octane Week, September 12, 1994, p. 10.

${ }^{12}$ Oxy-Fuel News, October 17, 1994, p. 1. 


\section{Imports}

As indicated in Part I of the study, gasoline imports are expected to be an important source of marginal RFG supplies to the Northeast. RFG imports for December and January are still expected to be 128 and $174 \mathrm{MBD}$, respectively, well within the capability of foreign refiners.

\section{Current and Expected Imports}

Petroleum product imports are driven mainly by domestic demand, as well as differences between foreign and domestic prices. So far, the incentive for RFG imports has been slight at best. As shown in Table 3, RFG imports for October and November 1994 trailed industry expectations. Because RBOB imports are included with imports of other unfinished blendstocks, RBOB imports may not be identified as such in the EIA data.

\section{Table 3. Reformulated Gasoline Imports}

(Thousand Barrels per Day)

\begin{tabular}{lrr}
\hline & Expected & Observed \\
October 1994 & 128 & 0 \\
November 1994 & 132 & 44 \\
December 1994 est. & 128 & - \\
January 1995 est. & 174 & - \\
\hline
\end{tabular}

Sources: Based on Energy Information Administration, Weekly Petroleum Status Report, DOE/EIA-0208(94) (Washington, DC, December 2, 1994, and earlier issues), and EIA Import Operations Questionnaire August and November 1994.

December and January imports, estimated to be 128 and $174 \mathrm{MBD}$, respectively, in Part I of the study, are still expected to be in that range. As indicated in the following section on potential foreign supplies of RFG, there is enough existing capacity to cover these import levels.

The RFG program is not expected to lead to an increase in total gasoline imports since the overall demand for gasoline will not change appreciably. Gasoline imports, predominantly required in the Northeast, will now arrive in the form of RFG or RBOB, as opposed to conventional gasoline. 


\section{Sources for RFG Imports}

Even though reported data indicate RFG imports to date are lower than expected, potential foreign supplies of RFG are adequate. Respondents to a survey conducted for EIA mentioned the potential for importing RFG not only from the Caribbean (including the Virgin Islands), Canada, and Venezuela, but also from Saudi Arabia, Belgium, Italy, and other countries that have supplied gasoline in the recent past. Another survey, conducted by Petroleum Intelligence Weekly, indicated that imports from refiners in the Western Hemisphere alone could cover the January requirement of 174 MBD (Figure 8). France and Spain could export a combined total of $48 \mathrm{MBD}$, while a refinery in Pembroke, United Kingdom, could export $30 \mathrm{MBD} .^{13}$

Figure 8. Potential RFG Supplies Available to the United States (258 Thousand Barrels per Day Total)

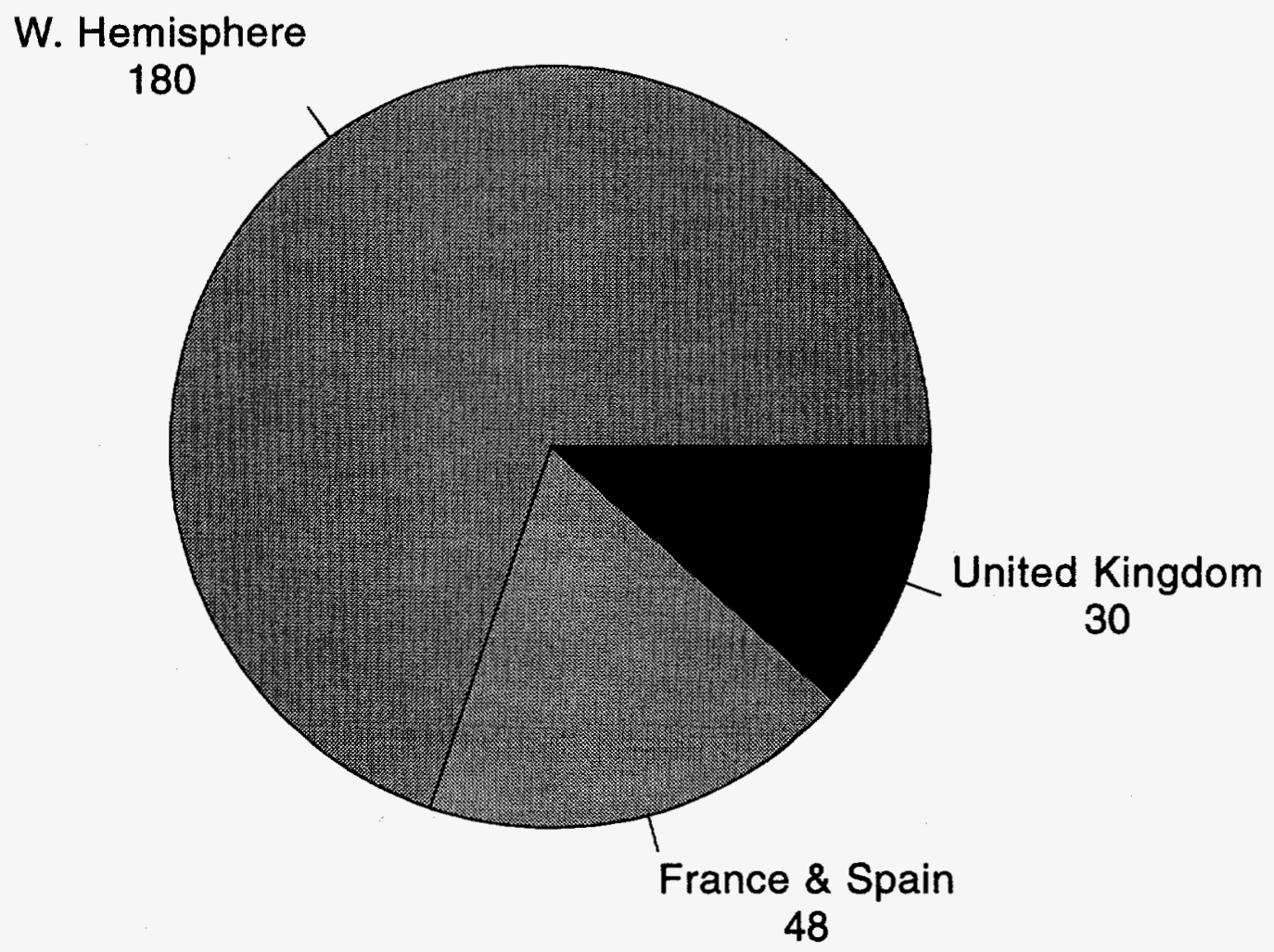

Source: Petroleum Intelligence Weekly, October 17, 1994.

${ }^{13}$ Petroleum Intelligence Weekly, October 17, 1994. 
Although sufficient foreign RFG capacity appears to exist, independent marketers that sell imported gasoline have argued that they may not be able to buy RFG from their usual suppliers. ${ }^{14}$ Nevertheless, disruptions in imports are not expected as marketers identify new supply sources.

Venezuela claims production capacity of about 100 MBD of RFG for export to the United States if allowed to use its own baseline for limiting emissions, rather than being subject to the stricter requirements of the 1990 U.S. average baseline. Given the tighter U.S. baseline requirements, some industry analysts have estimated likely exports to the United States at 32 to 82 MBD of RFG, depending on prevailing economics. ${ }^{15}$

Venezuela has asserted that by not according it equal treatment with U.S. refiners, the United States violated the General Agreement on Tariffs and Trade (GATT). A GATT panel has been formed to review the decision that requires Venezuela to use the U.S. average baseline. As of December 7, 1994, a meeting date for the panel had not been established.

${ }^{14}$ The Oil Daily, September 23, 1994.

${ }^{15}$ Petroleum Intelligence Weekly, September 19, 1994. 



\section{Stocks}

Total gasoline stocks currently are within the average range of gasoline stocks for this time of year and should provide adequate working inventory and surge capacity. Stocks of RFG and other types of gasoline are required for working inventory and surge capacity to accommodate demand changes, including seasonal demand variations. Total gasoline stocks increased for the fifth consecutive week to $214.7 \mathrm{MMB}$ as of December 2, 1994, from an unusually low 197.7 MMB on October 28, 1994. The low October level resulted from a combination of factors, including reduced production due to refinery turnarounds, flood-related disruptions in shipments on the Colonial Pipeline, and drawdowns of conventional gasoline in preparation for the introduction of RFG.

RFG stocks are low, as expected. Table 4 shows reported RFG stock levels for November 25 and December 2, and stock forecasts from Part I of the RFG assessment.

Table 4. Weekly RFG Stocks (November 25, 1994 and December 2, 1994) and Forecast (Million Barrels)

\begin{tabular}{crrr}
\hline & \multicolumn{1}{c}{ Actual } & Actual & \multicolumn{1}{c}{$\begin{array}{c}\text { Part I } \\
\text { Study Forecast }\end{array}$} \\
PADD & Nov. 25 & Dec. 2 & Nov. 30 \\
\hline I & 14.9 & 23.4 & 23.4 \\
II & 1.9 & 2.7 & 5.6 \\
III & 9.1 & 10.4 & 4.0 \\
IV & 0.0 & 0.0 & 0.0 \\
V & 1.4 & 2.3 & 8.2 \\
U.S. & 27.2 & 38.9 & 41.3 \\
\hline
\end{tabular}

Note: Stocks in columns labelled "Actual" reflect RFG stocks from ElA weekly surveys. Part I Study Forecast refers to forecasts from EIA's October RFG assessment (Part I).

Table 4 shows that total RFG stocks were slightly below forecast levels on December 2. PADD I stocks were at the forecast level, and PADD III stocks were over twice the forecast level. High RFG stocks in PADD III were at least partly due to disruptions in shipments to PADD I due to flood-related pipeline damage near Houston in late October. Refinery production from the Houston area could not be shipped out by pipeline during the disruption, causing a throughput 
reduction on the entire system. Overall RFG stock levels were also affected by disrupted pipeline flows because of cutbacks in refinery runs that reduced production of all types of gasoline.

To place these stock levels in perspective, Table 5 translates the levels into days of supply. As shown in the table, finished motor gasoline stocks have historically averaged about 24 days of supply at the end of November. While RFG stocks may eventually reach typical gasoline stock levels on a days of supply basis, RFG stocks are expected to be low during the transition. As discussed in the Introduction, the reported data shown in Table 5 are thought to understate actual RFG stocks and overstate conventional and oxygenated gasoline stocks. For example, reported conventional stocks imply 30 days of supply, which is somewhat higher than typical levels, based on historical averages. Taking into consideration reporting problems and reclassification, EIA estimates that actual RFG stocks at the end of November range between 17 and 19 days of supply, rather than the 15 days of supply shown in Table 5. Correspondingly, conventional and oxygenated gasoline stocks are believed to be lower than the table shows. Similarly, EIA estimates that RFG stocks will actually be 18 to 20 days supply at the end of December 1994, rather than the 16 days shown in Table 5.

Table 5. U.S. Stock Levels on December 2, 1994 (Days of Supply)

\begin{tabular}{l|c|c|c|c}
\hline & & & & $\begin{array}{c}\text { Average } \\
\text { Historical } \\
\text { Finished } \\
\text { Gasoline }\end{array}$ \\
\hline Dec. 2, 1994 & RFG & Conventional & Oxygenated & 12 \\
End of December 1994 (Forecast) & 16 & 34 & 12 & 24 \\
\hline
\end{tabular}

Notes: Days of supply is defined as ending month stocks divided by next month's average daily demand. Reported RFG stocks of 38.9 MMB and forecast December demand of 2,608 MBD were used to derive 15 days as of December 2. The end of December RFG days supply is based on a forecast stock increase of $1.4 \mathrm{MMB}$ and January demand of 2,453 MBD.

Source: Energy Information Administration, Weekly Petroleum Status Report, DOE/EIA-0209(94) (Washington, DC, December 2, 1994).

EIA's assertion that the reported data understate RFG stocks is based on:

- Forecast RFG stock levels included RBOB, which is not included in RFG stocks reported on EIA weekly surveys. (It is reported under motor gasoline blending components.) Stocks of RBOB are currently estimated at over $2 \mathrm{MMB}$.

- Reclassification of oxygenated and conventional gasoline stocks to RFG was expected to occur up until December 1, 1994, at which time RFG was the only gasoline which could be shipped to mandated and opt-in RFG areas. While most of this reclassification occurred prior to December 1, additional reclassified gasoline may be reflected in EIA data due to 
reporting lags. Reclassification is expected to have the largest impact on stocks in PADDs I and V.

- In addition to reclassification, EIA expected other reporting problems. As discussed in the Introduction, some companies may be reporting RFG erroneously as conventional or oxygenated gasoline. Also, waterborne RFG volumes may not be fully captured.

- Finally, new supplies (refinery production and imports) of RFG since the beginning of September 1994 have been reported at nearly $52 \mathrm{MMB}$, about $13 \mathrm{MMB}$ more than the current stock level of $38.9 \mathrm{MMB}$. This suggests that industry has already made significant progress in moving RFG to secondary storage. Secondary storage is expected to hold about 17 MMB of RFG when the program is fully implemented beginning January 1, 1995.

In summary, reported RFG stocks are low entering December, as expected during this product transition. However, it is EIA's assessment that reclassification and other reporting problems have partially obscured actual RFG stock levels, which are estimated to be closer to $45 \mathrm{MMB}$, or at least 17 days of supply. Stocks are likely to remain low through December, as discussed in the Supply and Demand Balance section. Barring unexpected supply or delivery problems, working inventories of RFG are expected to be adequate. 


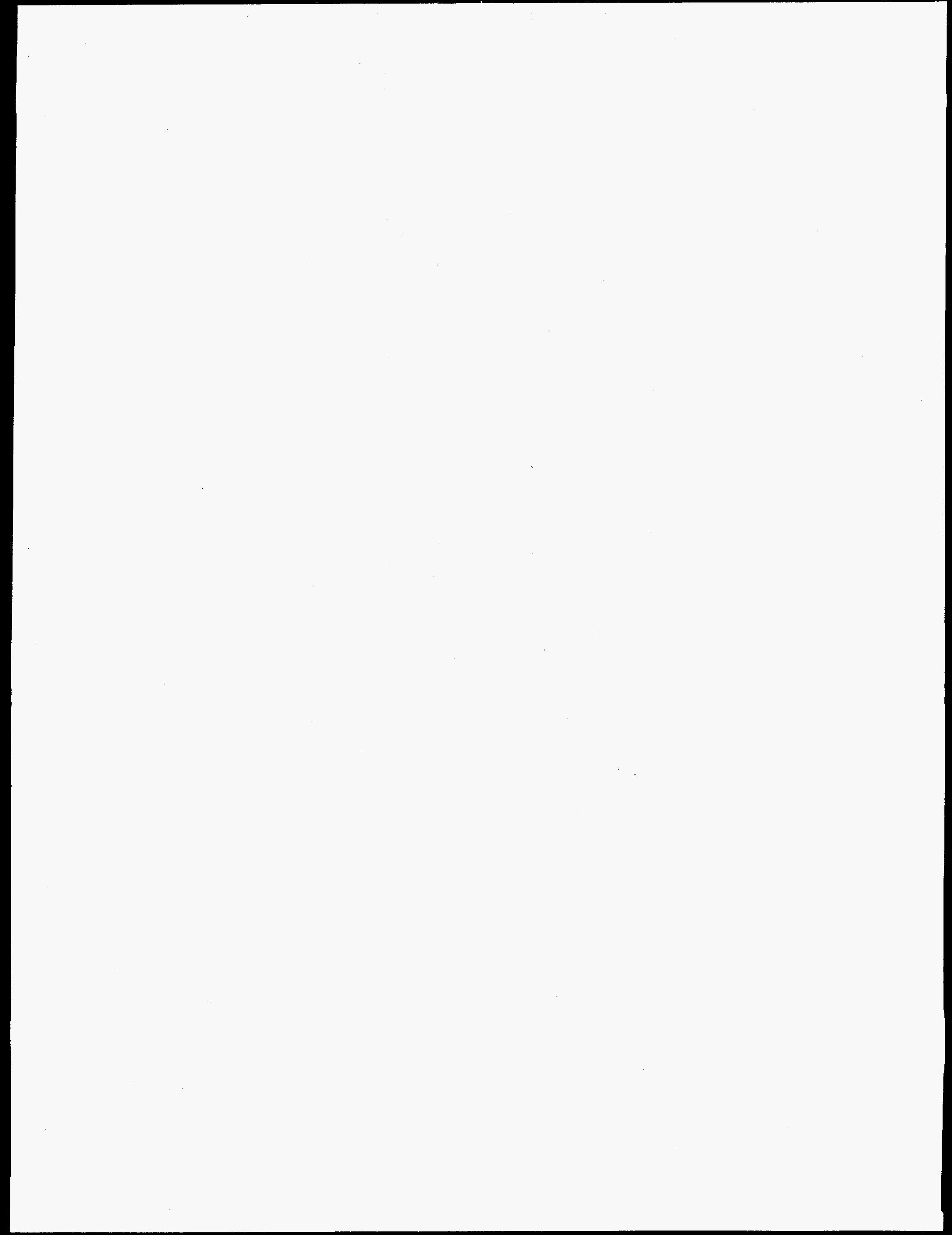




\section{Supply and Demand Balance}

The latest EIA estimates of RFG and OPRG supply and demand balances for December and January are tight, which is consistent with a new product transition and with the tight supply-demand balance situation discussed in Part I of the RFG assessment.

Supply on a short-term basis comes from production and imports, and from stocks when production and imports are inadequate to meet demand. A balance is considered "tight" when production availability and stock levels are too low to prevent shortages arising if a disruption to supply occurs.

While estimates of December RFG and OPRG production and imports seem to be adequate to meet demand, RFG stock levels at the end of November are relatively low, and only small stock increases are projected to occur during the month. Thus, December ending stocks may still be low, leaving little room to absorb unexpected disruptions to supply. As discussed in Part I of the study, PADD I will receive its marginal RFG supplies mainly from PADD III and from imports, and neither of these sources is likely to be able to provide quick relief should a refinery in PADD I have to shut down unexpectedly. PADD V is beginning the RFG program in December with low apparent stock levels, and is virtually isolated from other domestic supply sources. Any significant supply difficulties in this area could result in outages of RFG.

The update of the January supply-demand balance discussed at the end of this section does not change the conclusion from Part I of the study. The January balance is still tight, but the updated information indicates an opportunity for higher stock builds during the month than shown in Part I of the study.

\section{December Gasoline Supply and Demand Balance}

\section{Total Gasoline}

The December total gasoline supply-demand balance is forecast to maintain comfortable stock levels, based on historical averages. As described in the earlier sections, total gasoline demand in December is expected to be higher than in January, and total gasoline production is forecast to be higher as well. The Market Clearing Estimate shown in Table 6 shows 7,681 MBD of total gasoline production ${ }^{16}$ available to meet the 7,683 MBD of demand. This December production

\footnotetext{
${ }^{16}$ Production available was derived from an update of the August survey on planned production and on EIA estimates from non-respondents.
} 
Table 6. Market Clearing Estimate by Type of Gasoline, December 1994 (Thousand Barrels per Day)

\begin{tabular}{|c|c|c|c|c|c|c|}
\hline & Production & $\begin{array}{c}\text { Net } \\
\text { Receipts }\end{array}$ & $\begin{array}{c}\text { Net } \\
\text { Imports }\end{array}$ & $\begin{array}{c}\text { Stock } \\
\text { Change }\end{array}$ & $\begin{array}{c}\text { Total } \\
\text { Supply }\end{array}$ & Demand \\
\hline \multicolumn{7}{|l|}{ PADD I } \\
\hline$R F G+$ OPRG & 677 & 615 & 128 & 18 & 1,402 & 1,402 \\
\hline Oxygenated & 20 & 36 & 0 & 0 & 56 & 56 \\
\hline Conventional & 114 & 991 & 40 & 29 & 1,116 & 1,116 \\
\hline Totals: & 811 & 1,642 & 168 & 47 & 2,574 & 2,574 \\
\hline Dec 93 & 788 & 1,636 & 228 & 106 & 2,545 & 2,545 \\
\hline \multicolumn{7}{|l|}{ PADD \| } \\
\hline RFG + OPRG & 292 & 82 & 0 & 0 & 374 & 374 \\
\hline Oxygenated & 136 & (54) & 0 & (2) & 84 & 84 \\
\hline Conventional & 1,452 & 442 & 0 & 1 & 1,893 & 1,893 \\
\hline Totals: & 1,880 & 470 & 0 & (1) & 2,351 & 2,351 \\
\hline Dec 93 & 1,905 & 414 & 0 & (19) & 2,338 & 2,338 \\
\hline \multicolumn{7}{|l|}{ PADD III } \\
\hline RFG + OPRG & 1,029 & $(730)$ & 0 & 12 & 287 & 287 \\
\hline Oxygenated & 95 & (63) & 0 & (10) & 42 & 42 \\
\hline Conventional & 2,311 & $(1,419)$ & 0 & 46 & 846 & 846 \\
\hline Totals: & 3,435 & $(2,212)$ & 0 & 48 & 1,175 & 1,175 \\
\hline Dec 93 & 3,448 & $(2,123)$ & (91) & 21 & 1,214 & 1,214 \\
\hline \multicolumn{7}{|l|}{ PADD IV } \\
\hline RFG + OPRG & 0 & 0 & 0 & 0 & 0 & 0 \\
\hline Oxygenated & 40 & 56 & 0 & 0 & 96 & 96 \\
\hline Conventional & 195 & (35) & 0 & 18 & 142 & 142 \\
\hline Totals: & 235 & 21 & 0 & 18 & 238 & 238 \\
\hline Dec 93 & 224 & 0 & 0 & (3) & 228 & 228 \\
\hline \multicolumn{7}{|l|}{ PADD V } \\
\hline RFG + OPRG & 528 & 33 & 0 & 16 & 545 & 545 \\
\hline Oxygenated & 580 & 25 & 0 & (20) & 625 & 625 \\
\hline Conventional & 212 & 21 & 0 & 58 & 175 & 175 \\
\hline Totals: & 1,320 & 79 & 0 & 54 & 1,345 & 1,345 \\
\hline Dec 93 & 1,360 & 73 & (69) & 27 & 1,337 & 1,337 \\
\hline \multicolumn{7}{|l|}{ TOTAL US } \\
\hline$R F G+O P R G$ & 2,526 & 0 & 128 & 46 & 2,608 & 2,608 \\
\hline Oxygenated & 871 & 0 & 0 & (32) & 903 & 903 \\
\hline Conventional & 4,284 & 0 & 40 & 152 & 4,172 & 4,172 \\
\hline Totals: & 7,681 & 0 & 168 & 166 & 7,683 & 7,683 \\
\hline Dec 93 & 7,725 & 0 & 69 & 132 & 7,661 & 7,661 \\
\hline
\end{tabular}

Notes: Production plus imports plus net receipts minus stock change equals total supply, which in turn, equals demand. Totals may not equal sum of components due to independent rounding. Negative quantities are shown in parenthesis. Net Received (Net Recd.) equals the difference between gross receipts and gross shipments. December 1994 imports are the difference between gross imports and gross exports. PADD 1 receipts and shipments exclude movements between sub-PADDs.

Source: Petroleum Supply Annual, 1993. EIA estimates. 
estimate is slightly lower than both December 1993 production of 7,725, and production during November 1994 (as reported in EIA's Weekly Petroleum Status Report, December 2, 1994).

Together, production and imports in the Market Clearing Estimate were able to support demand and an overall gasoline stock build of $166 \mathrm{MBD}$, which would increase stocks by about 5.1 MMB over the month of December. Recall that total gasoline stock levels at the end of November have recovered from the low October levels discussed in the stock section. As shown in Table 7, while EIA does not expect a stock increase during December much larger than 5 MMB, total gasoline stocks should end December at comfortable levels.

Table 7. RFG Market Clearing Estimates (Including OPRG), December 1994 (Thousand Barrels per Day)

\begin{tabular}{|c|c|c|c|c|c|c|}
\hline PADD & Production & $\begin{array}{c}\text { Net } \\
\text { Receipts }\end{array}$ & $\begin{array}{c}\text { Net } \\
\text { Imports }\end{array}$ & $\begin{array}{c}\text { Stock } \\
\text { Build } \\
\text { (Draw) }\end{array}$ & $\begin{array}{l}\text { Total } \\
\text { Supply }\end{array}$ & Demand \\
\hline IA & 0 & 298 & 35 & 0 & 333 & 333 \\
\hline IB & 658 & 214 & 91 & 16 & 947 & 947 \\
\hline IC & 19 & 103 & 2 & 2 & 122 & 122 \\
\hline I Total & 677 & 615 & 128 & 18 & 1,402 & 1,402 \\
\hline II & 292 & 82 & 0 & 0 & 374 & 374 \\
\hline III & 1,029 & (730) & 0 & 12 & 287 & 287 \\
\hline IV & 0 & 0 & 0 & 0 & 0 & 0 \\
\hline v & 528 & 33 & 0 & 16 & 545 & 545 \\
\hline U.S. Total & 2,526 & 0 & 128 & 46 & 2,608 & 2,608 \\
\hline
\end{tabular}

Notes: Totals may not equal sum of components due to independent rounding. Negative quantities are shown in parentheses (). Net Receipts equals the difference between gross receipts and gross shipments.

Source: EIA estimates.

\section{Reformulated Gasoline}

Unlike total gasoline, the estimated December RFG supply-demand balance is tight (Table 7). EIA's latest estimates of RFG and OPRG production during December total 2,526 MBD, 87 MBD higher than production shown for January 1995 in the earlier RFG assessment report, but in line with updated January production plans provided by refiners as discussed in the Domestic Production section. Import levels for December are projected to be $128 \mathrm{MBD}$, the level reported 
in Part I of the study. Estimated December production, along with an estimated $128 \mathrm{MBD}$ of imports to PADD I, support an RFG and OPRG stock build of $46 \mathrm{MBD}$ (or a $1.4 \mathrm{MMB}$ increase for the month) and demand of 2,608 MBD.

The December RFG ending stock level implied from the supply-demand balance is low, but consistent with what might be expected during a product transition. The ending December stock level is also lower than the stock levels discussed in Part I of the RFG assessment, but still seems to be within a minimum working level. The small stock increase shown in the market clearing case is more typical of gasoline stocking patterns during December. EIA still believes this lower level of inventory is adequate.

While supply disruptions are a concern when stocks are low, uncertainties in some assumptions underlying the supply-demand balance have potential to improve the situation. Some refiners have indicated they have capacity to produce more RFG and OPRG than planned for December and January. EIA does not know exactly how much extra RFG capacity is available, or how fast the capacity can be made available. However, there are indications that production may have some room for limited upward adjustment. Also, EIA demand estimates assume a 5 percent spillover factor for RFG. If spillover is only 3 percent (which is still higher than the 1 percent experienced with oxygenated gasoline), RFG and OPRG demand will be 50 MBD lower in December, allowing for an RFG and OPRG inventory build of an additional 1.6 MMB during the month. If the opt-in areas of Pennsylvania leave the program in early December, production capability exists to provide another $5 \mathrm{MMB}$ of stock build. While a $5 \mathrm{MMB}$ increase still leaves stocks low, such an increase would improve the chances of a smooth transition. As discussed previously, any price increases may provide incentives for more imports and more production.

\section{January RFG Supply and Demand Balance Update}

Taking into consideration more recent information for January, the conclusions reached in Part I of the RFG assessment for the January supply-demand balance have not changed. That is, the January supply-demand balance shows little ability to absorb any unexpected supply or delivery disruptions. Table 8 highlights the major changes to the January balance.

Updated information affecting the January supply-demand balance includes:

- Increased planned production of RFG and OPRG: Information provided to EIA during October and November by refiners indicates that the industry is planning about $100 \mathrm{MBD}$ more production in January than was published in Part I of the study.

- Lower total gasoline demand: The most recent estimate of total gasoline demand for January is $7,100 \mathrm{MBD}$, which is about $190 \mathrm{MBD}$ less than the demand estimated in Part I of the study. This implies a reduction in RFG and OPRG demand of about $66 \mathrm{MBD}$. 
Table 8. January U.S. Total RFG Supply and Demand Balance Update (Thousand Barrels per Day)

\begin{tabular}{l|c|c|c|c|c}
\hline & Production & Net Imports & Stock Builds & Total Supply & Demand \\
\hline Part I & 2,439 & 174 & 96 & 2,519 & 2,519 \\
Part II Update & 2,539 & 174 & 260 & 2,453 & 2,453 \\
\hline
\end{tabular}

Note: Totals may not equal sum of components due to independent rounding.

Source: EIA estimates.

- Import levels will be at least as high as estimated in Part I of the study: Imports of RFG, OPRG, and RBOB are still expected to be about $174 \mathrm{MBD}$, but industry reports indicate that more may be available.

- Although the changes indicated above present more opportunity for stock builds, January RFG stock levels are likely to be low: As discussed in the Stocks section, ending December stock levels are expected to be lower than anticipated in Part I of the study. However, the increases in January production and decreases in January demand imply production capacity would be available to add about another $5 \mathrm{MMB}$ to stocks, offsetting the lower ending December stock level to some extent. Also, Pennsylvania's possible withdrawal from the RFG program could free more production for stock builds, perhaps an additional $5 \mathrm{MMB}$. Although current information for January suggests some improvement in supply, a large degree of uncertainty continues to surround these estimates. 


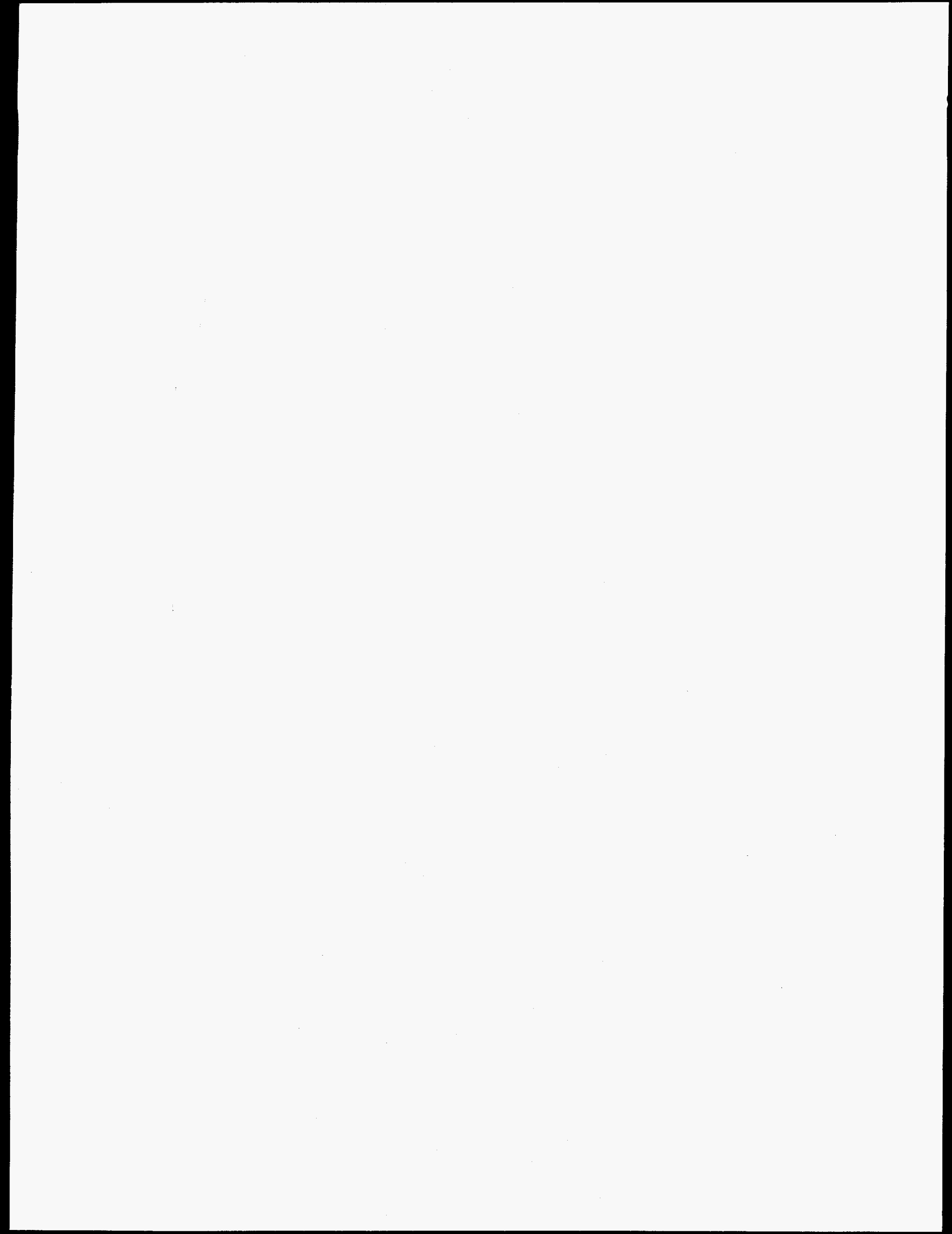




\section{Deliverability}

Transportation modes for delivering gasoline to the retail market were outlined in Part I of this report. The assessment pointed out that the RFG program reduced the distribution system's flexibility, possibly resulting in dislocations that could be difficult to respond to in a timely fashion. A transportation disruption did in fact occur just as RFG shipments from the major refining center of the Gulf Coast were beginning to move through the Colonial Pipeline to the major consuming areas of the Northeast.

\section{The Colonial Pipeline Emergency}

Colonial is the largest product pipeline in the United States, stretching more than 1,000 miles from the Gulf Coast to the Northeast. It is composed of lines 1 and 2 , the former devoted exclusively to shipping motor gasoline and the latter to transporting gasoline and other products, primarily distillates. With a maximum capacity of $2,200 \mathrm{MBD}$, Colonial is the principal petroleum supply artery for the Northeast.

Texas experienced torrential rains during October, causing severe flooding of the San Jacinto River. The flood waters changed the course of the river exposing several pipelines at a crossing near Houston. On October 20,1994, both of Colonial's main lines failed. The section from Houston to Beaumont, which accounts for approximately 40 percent of Colonial's throughput, was closed. The initial shipments of RFG were reportedly in the pipeline when this occurred.

With the pipeline disabled east of Houston, companies moved product by truck and barge further eastward to Beaumont, Texas for injection into Colonial at that point, so that the remaining portion of the pipeline could stay in operation. In addition, refiners beyond Beaumont increased production and drew down their stocks to maintain pipeline fill. Other companies used tankers that they either owned or chartered to move RFG to the Northeast.

By November 2, 1994, Colonial had reestablished transportation from the Houston area by temporary repairs to its No. 2 line across the river. Alternating shipments of gasoline and distillates were carried east to Beaumont where the respective products were segregated into the appropriate lines. Accordingly, the Houston area refineries, which were forced to reduce their operations when the pipeline mishap occurred, resumed full operations. A second temporary link for the No. 1 line was operational on December 5, 1994.

Fortunately, this mishap occurred in the initial stage as the first RFG shipments were beginning to move to the Northeast. Rapid response to the emergency minimized the impact. Industry estimates suggest that as little as 2 MMB of RFG may have been delayed in moving into Northeastern inventories by the pipeline disruption. Over time, these volumes would likely be 
made up by increased refinery production and continued marine shipments to supplement pipeline deliveries.

\section{Follow-up Survey}

Several major pipeline companies were contacted to gather current information relative to RFG shipments. December nominations, the impact of product testing, and deliverability of other products were discussed.

\section{December Pipeline Nominations}

Pipeline shipments are vital to the viability of the RFG program in the Northeast. For December, pipeline nominations of RFG and OPRG to the area are $719 \mathrm{MBD}$. This volume is consistent with the Market Clearing Estimate contained in Supply and Demand Balance.

\section{Hardware and Testing Availability}

Surveyed pipelines and large terminal operators indicated that they currently have no problems with the testing provisions of the RFG program. All either purchased and installed the appropriate testing equipment or have made testing arrangements with independent laboratories. Their consensus is that the testing requirements, at this point in time, will not result in a delay in the start-up of the RFG program.

\section{Deliverability of Other Fuels}

Several surveyed pipelines indicated that their customers had curtailed some November distillate nominations, citing lack of demand and distillate storage containment problems for the cancellations. Space is available on several pipelines for increased distillate shipments if needed. In essence, respondents indicated that there are no current problems involving the shipment of other fuels stemming from the RFG program.

Although the National Weather Service is forecasting warmer than normal temperatures for the Northeast and Midwest this coming winter, and distillate inventories are currently in the normal range, heating oil stocks are about $7 \mathrm{MMB}$ less than they were at this time last year. With heating supplies lower, if a prolonged, severe cold snap were to take place, respondents cautioned that the situation could change. Such a scenario would pit distillate fuel oil against gasoline for pipeline space and could create temporary problems for the RFG program. 


\section{Prices}

Concern has been expressed by industry, government, and consumer groups that the introduction of RFG will significantly impact gasoline prices, causing individual hardships, reduced driving (and hence economic activity), and dislocations to buying patterns. A portion of the anticipated effects has already been seen, and forecasts for the next several months vary greatly. However, current prices for RFG are consistent with the costs underlying the product, and the difference between RFG and conventional gasoline prices indicates confidence in supply.

\section{Recent Price Movements}

Gasoline prices, as seen by consumers at the pump, are the product of a variety of influences, including crude oil prices; refining, transportation, and marketing costs; Federal, State, and local taxes; and profit margins at all levels of the industry. During the course of the year, seasonality is also a significant influence, with gasoline prices tending to rise in the summer, due to higher demand, and to fall in the winter. On a year-to-year basis, all of these factors except crude oil prices are fairly constant. Thus, the major influence on gasoline prices over time is the price of crude oil to refiners, which is determined in a global market. In the case of oxygenated and reformulated gasoline, however, the separate cost of oxygenates blended into the fuel can be significant.

After dropping sharply in August and September, due to falling crude oil prices and the end of the summer driving season, spot market conventional gasoline prices began to rise in October on tightening supplies and anticipation of the complex changeover to RFG (Figure 9). The rupture of the Colonial Pipeline on October 20, due to flooding near Houston, further aggravated the situation, severing a major transportation artery as the changeover was beginning. New York Harbor spot conventional gasoline prices peaked at 60.8 cents per gallon on October 28, a week after the pipeline rupture, and have since fallen over 16 cents. Following Pennsylvania's announcement on December 1 of its intention to reverse its opt-in for 28 counties, spot prices fell over 4 cents per gallon, but partially recovered over the next several days. As of December 7 , spot prices were over 6 cents above the same point in 1993, largely attributable to crude oil prices being $\$ 2.33$ per barrel (5.6 cents per gallon) above last year.

New York Mercantile Exchange (NYMEX) gasoline futures prices for December, the first month representing RFG, traded nearly as much as 10 cents per gallon above November contract levels in the months preceding the start-up of the RFG program. However, following the Colonial Pipeline rupture, short-term supplies of conventional gasoline became a greater concern, and the differential began to shrink, as conventional gasoline price increases began to outpace those of RFG. After the pipeline was restored with a temporary connection on November 2 , the inflated price of conventional gasoline fell back. RFG futures, which had been less affected by the break, also retreated, but less sharply. The December NYMEX contract peaked at 59.8 cents per gallon 
Figure 9. Crude Oil and Gasoline Prices

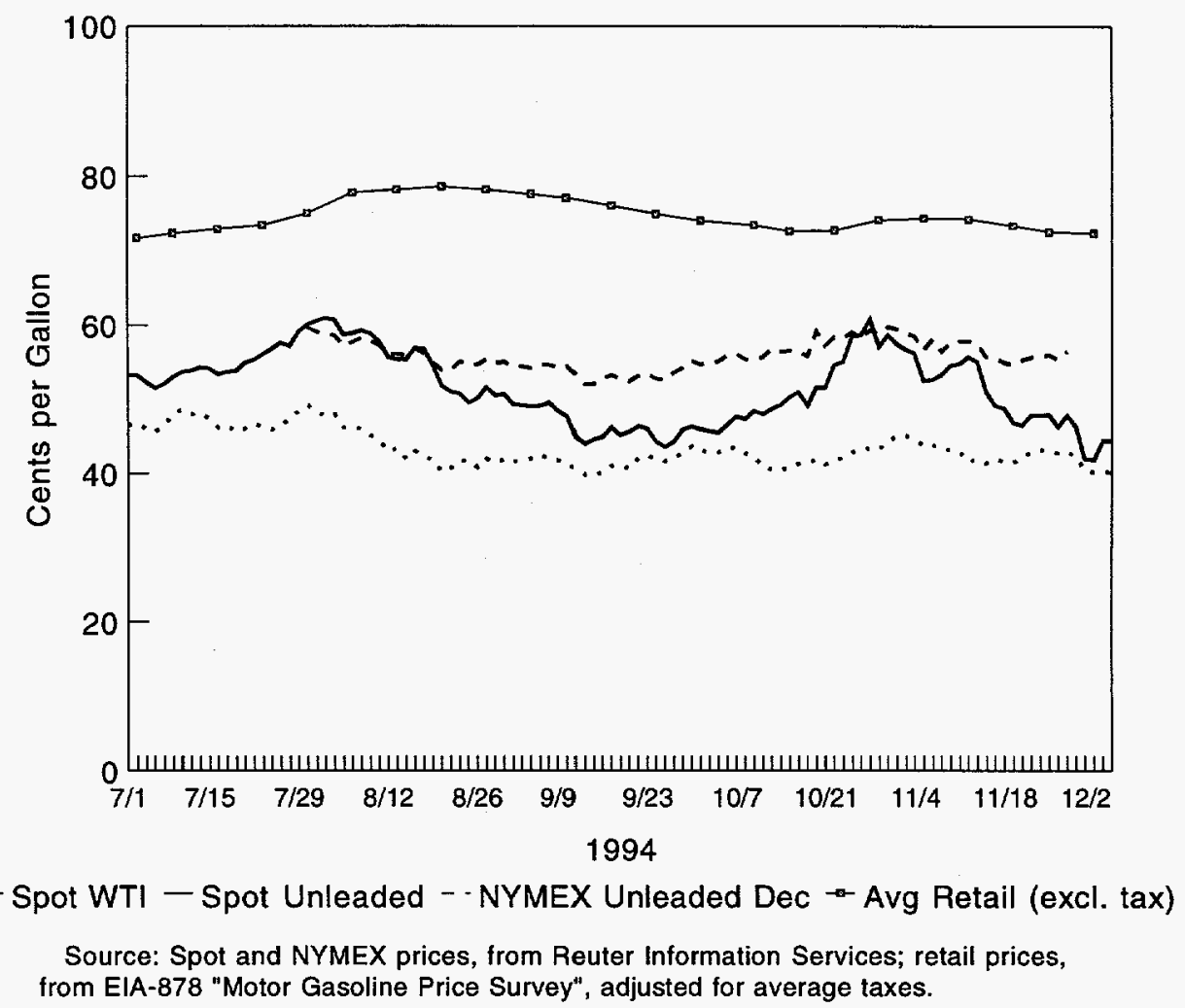

on November 1, and fell over 3 cents before expiring at the end of November. As of December 7, spot prices for RFG were about 49 cents per gallon in New York Harbor, and 47 cents on the Gulf Coast, 4 to 6 cents above those for conventional gasoline. EIA had earlier estimated the incremental cost of RFG production by refiners at 4 to 6 cents above conventional gasoline, but recent increases in oxygenate prices had inflated the cost differential until the sharp price drops following the Pennsylvania announcement. OPRG, which will be required through the winter on much of the East Coast, was 2 to 3 cents higher than non-oxygenated RFG.

Retail price changes typically lag those in spot and futures markets, as supply and demand pressures work their way through the system. As of December 5 , retail prices were generally 5 to 10 cents higher than a year ago, differing regionally, for both conventional and oxygenated gasolines. Although RFG is not yet officially sold at retail, trade press reports indicate that the shift to OPRG in areas requiring oxygenated fuel is occurring with little price impact, confirming that the cost of oxygenates is currently a greater determinant of prices than are other incremental costs of producing RFG.

\section{Expected Developments}

The evolution of RFG prices up to and after the official start-up of the RFG program on January 1,1995 , is very difficult to forecast, because it is unlike any transition yet experienced in petroleum product markets. However, the factors that will influence those prices are well 
understood, and some expectations about future price movements can be developed based on past behavior.

When consumers compare current retail prices to a year ago, the relationship will depend strongly on the type of gasoline sold in the area now versus then, i.e. local participation in the oxygenated and/or reformulated gasoline programs (Figure 10). In areas with conventional gasoline in both years, consumers may see about a 6 to 7 cent difference due mainly to crude oil costs (once the crude oil effect on spot prices is fully translated to retail). This differential is currently reflected in conventional gasoline prices in most areas, but may fluctuate during the transition due to local surpluses or shortfalls of conventional gasoline supply.

Figure 10. Gasoline Cost Factors, December 1993 and 1994

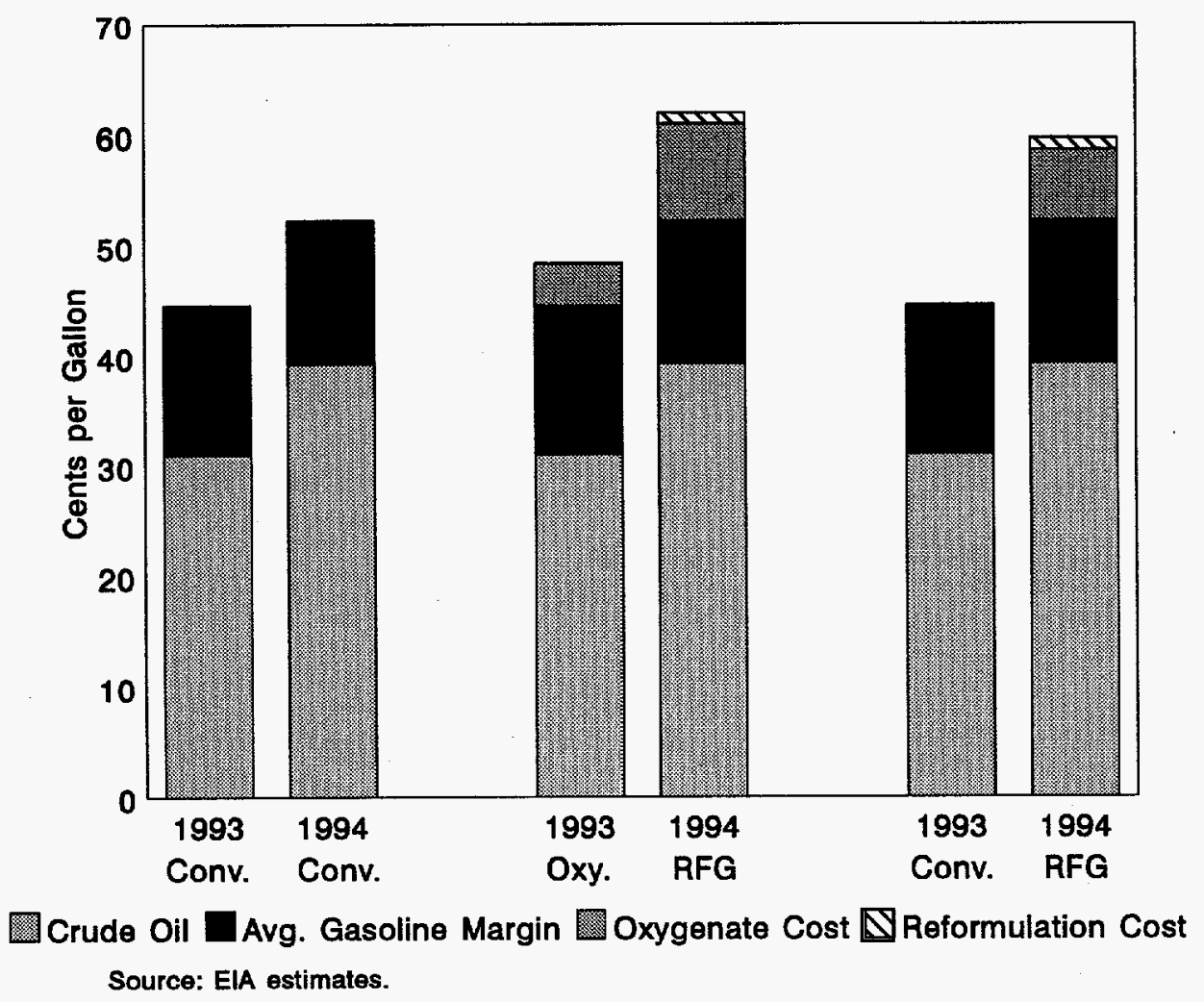

In areas requiring oxygenated gasoline both years, the year-to-year difference would be greater, due to higher prices for oxygenate additives than those a year ago. At an MTBE price of \$1.10 per gallon, as seen in November 1994, the cost of adding 15 volume percent MTBE to gasoline (needed to meet the 2.7 weight percent oxygenate target requirement) is about 9 cents per gallon, compared to about 5 cents in 1993. Thus the expected increase in oxygenated gasoline prices is about 10 cents at present, allowing for the increased cost of oxygenates in addition to higher crude oil prices. For areas requiring OPRG this year, and oxygenated gasoline last year (prevalent on the East Coast), the expected difference would be 11 to 12 cents, based on other incremental production costs for RFG. 
The greatest year-to-year increase would be expected for those purchasing RFG this year in areas formerly using conventional gasoline, where prices could be up as much as 15 cents from last year, combining higher crude oil costs with the incremental cost of RFG over conventional. In areas that do not also require oxygenated gasoline during the winter season, RFG must have an oxygen level of 2.0 weight percent. This blend requires about 11 volume percent MTBE, costing about 6 cents per gallon at current prices.

All of the above comparisons, of course, reflect only influences seen to date, and could easily change with further developments in crude oil or oxygenate prices, refinery or distribution problems, or simply the temporary market imbalances that typically surround new product introductions. Previous new product introductions provide two scenarios for comparison. The introduction of oxygenated gasoline in November 1992 was accomplished with less disruption than expected, and with price impacts of only 3 to 5 cents per gallon, approximately the incremental cost of oxygenation. By contrast, the nationwide changeover to low-sulfur onhighway diesel fuel in October 1993 was problematic, with regional product shortfalls and temporary local price run-ups of as much as 30 cents per gallon. There were a number of significant differences between the two introductions, including the programs themselves (gasoline versus diesel fuel, regional versus nationwide, and seasonal versus year-round), and unrelated infrastructure (refinery and pipeline) problems. However, one notable factor is that each additional program requiring further product segregation increases the potential for supply disruptions, due to limitations in the distribution system, and lengthens the time needed for resupply. Any such disruption, most likely on a local level, can be expected to cause a temporary imbalance in prices, as local markets compete with each other for limited available supplies. 


\section{Recent Government Activity}

\section{Environmental Protection Agency}

EPA is attempting to grant all approvals and waivers in time for full implementation of the RFG program. All refiners, blenders and importers must submit a 1990 baseline so that the quality of their RFG can be compared to the quality of their 1990 conventional gasoline. In-line blending waivers are required to facilitate RFG production and testing.

\section{Baselines}

As of December 7, 1994, EPA had received 138 statutory baselines and had approved all of them. EPA had also received 142 individual baselines, but approved only 30. According to EPA, two major problems exist with the individual baseline submissions. The first is incomplete information. In most instances, the missing information is the justification for the approach the company took to calculate its baseline. The second problem relates to "methodological errors," which relate to the amount of flexibility granted to a company by the RFG regulations in determining its baseline. EPA feels that some applicants have stretched this flexibility to achieve favorable results. However, EPA still intends to make final decisions on all individual baselines by January 1, 1995.

\section{In-line Blending Waivers}

As of December 7, 1994, EPA had received applications from seven companies for in-line blending waivers. Waivers had been granted to five companies covering 13 refineries. Two applications remained under consideration at that time.

\section{Energy Information Administration}

On an ongoing basis, EIA is keeping EPA, the Department of Transportation and other government agencies informed about the start-up of the RFG program. For example, each week copies of EIA's RFG Watch (a fact sheet on production, stocks, and imports) and the Petroleum Market Report are electronically transferred to EPA.

As necessary, EIA provides industry insight during this monitoring phase. On November 22, 1994, EIA met with EPA's Office of Mobil Sources - Field Operations. The intent was to provide information to EPA's regional offices on current RFG spot and futures market prices, detail on the cost differential between RFG and conventional gasoline, and a comparison of cost estimates from a variety of studies. 
In addition, EIA is participating in EPA's RFG Taskforce's Emergency Scenarios Subgroup. The first meeting, held November 2, 1994, was spent identifying issues and participants to be involved should an RFG supply disruption arise:

- Participants discussed the types of information EPA will need to assess such "emergencies," and how the Agency might communicate and interact with the Department of Energy, various State energy offices, and industry in such a situation.

- EPA stated its intent not to give product-quality waivers to provide relief to parties who failed to adequately plan RFG production. Waivers would be considered only for "act-ofGod"-type emergencies.

- The group reviewed the relationship between supply problems and price.

Members of the EPA's RFG Taskforce's Emergency Scenarios Subgroup include representatives of refiners, pipeline companies, terminal operators, industry trade associations, the National Association of State Energy Officials, and government agencies.

EIA will continue to work with EPA to ensure a successful transition to RFG. 